Article

\title{
Investigating the Role of the Local Community as Co-Managers of the Mount Cameroon National Park Conservation Project
}

\author{
Nvenakeng Suzanne Awung ${ }^{1,2, *}$ and Rob Marchant ${ }^{1}$ \\ 1 York Institute for Tropical Ecosystems, Environment Department, University of York, YO10 5NG, UK; \\ robert.marchant@york.ac.uk \\ 2 The Forgotten Green Heroes, Buea Post Box 294, Cameroon \\ * Correspondence: s.nvenakeng@cbe9.be or nvenakeng.s@gmail.com; Tel.: +32-466-442-860 \\ Academic Editors: Yu-Pin Lin, Dirk S. Schmeller, Wei-Cheng Lo and Wan-Yu Lien \\ Received: 17 October 2016; Accepted: 8 December 2016; Published: 15 December 2016
}

\begin{abstract}
Local forest management is essential for enhancing the sustainability of both communities' livelihoods and Reducing Emissions from Deforestation and Land Degradation (REDD+) projects. However, few studies have examined the impact of forest ownership and control on community engagement and the functioning of communities in a co-managing conservation initiative. This paper examines the influence of forest management on local participation and identifies the roles/functions of local communities in the Mount Cameroon National Park REDD+ conservation project. Cluster multi-stage random sampling was used to collect data from 259 respondents that were analysed using the chi-square, Mann-Whitney, $t$-test, Kruskal-Wallis, Jonckheere-Terpstra tests and NVivo. Results show that local communities have been involved in forest management practices before the establishment of the park. Communities support the establishment of a strict conservation zone and hope to promote local participation with a high expectation of benefits. Insecure tenure reduces project support and local engagement. Though communities massively support the initiative, engagement is low, and participants are not carrying out any tangible roles. They function mainly as manual labourers or mere committee members who only enforce rules/regulations within communities. Community-based natural resource management and integrated conservation and development projects have often not realised local expectations due to problems of application and impracticable legislation. Projects' failure may be avoided by involving communities in tangible roles/functions and developing an effective co-management approach or establishing community-owned and -managed forest projects. This paper examines the progress of REDD+ from an early stage to help inform proponents in adapting strategies that are geared towards appropriate satisfactory outcomes, especially for local communities, to prevent the early failure of the initiative.
\end{abstract}

Keywords: community-based natural resource management; integrated conservation and development projects; REDD+ social safeguards

\section{Introduction}

About 80 million $\mathrm{km}^{2}$ are covered by protected areas that make up $12.2 \%$ of the land surface, and almost one-sixth of the world's population (1.1 billion) depends on them for livelihood [1]. Indigenous peoples have inhabited and conserved forest for centuries, and much land is still under community management [2]. Although members of local communities are not the major cause of climate change, the impact is felt mostly by them [3]. As cited by Maxime et al. [4], protected areas have existed in different forms within different cultures as far back as pre-agrarian societies, and sacred forest existed before, in which extractive use of natural resources was prohibited. Royalty sets aside land for 
game hunting, which acts as a reserve with the exclusion of commoners. Therefore, conservation is an old practice of indigenous people, and local communities should be considered in all forest projects where their rights to ownership are not interfered. Reducing Emission from Deforestation and Land Degradation (REDD+) is based on experiences with Payment for Ecosystem Services (PES) and the United Nations forest-related negotiations, which have slowly shifted conservation programmes from local to a more global scale [5]. Nevertheless, its implementation still requires sub-national projects such as Integrated Conservation and Development Projects (ICDP) and Community-Based Natural Resource Management (CBNRM) [6]. However, few studies have examined how REDD+ is being examined at these scales. Mount Cameroon National Park (MCNP) REDD+ initiative has an element of ICDP (conservation project), as well as CBNRM (sustainable management of Prunus africana); therefore, the principles and lessons learned from ICDP and CBNRM are essential tools in designing and implementing MCNP-REDD+ projects.

As reported by Minang and van Noordwijk [7], REDD+ programs are often implemented through conservation programs, and many REDD+ pilot projects are currently built on ICDPs. The collaborative management approach and the conservation incentives concept of MCNP are considered as implementing strategies for REDD+, which aims at effective management and conservation of natural resources and biodiversity while rendering socio-economic benefits. ICDP is a conservation project with the inclusion of a rural development component [8] for achieving sustainable development, and this is a widely-applied approach to achieving conservation, which also holds a wealth of experience for REDD+, including lessons on inherent and design challenges. Conservation can be deployed in REDD+ strategies in two ways: when ICDP is used as a platform for launching REDD+ at the landscape/sub-national level; and when conservation is one of several strategies for REDD+ at the national level [7]. According to Cerbu et al. [9], integrated conservation and development projects are part of REDD+ strategies, and using REDD+ incentives for forest conservation will only compliment emission reduction management objectives for park conservation. This is because present REDD+ projects follow ICDP concepts, and local knowledge and capacity developed on conservation activities can be used for measurement, report and verification requirements for REDD+. Conservation also emerges from the Cancun agreement making MCNP suitable as REDD+ projects.

CBNRM is a holistic approach that supports participatory, interdisciplinary and multi-level stakeholders networking in addressing complex socio-ecological issues that are geared towards sustainable development. Collaboration of experts, non-experts and members of local communities is instrumental in structuring effective CBNRM initiatives [10]. However, a lack of recognition of communities' values, market values and elite capture often contradict the concept [11]. Therefore, a holistic interdisciplinary approach is necessary to better understand and address these complex socio-environmental issues. Organisational design principles that are frequently associated with successful CBNRM include sensitisation and community engagement, collaborative partnership, resource and equity, effective communication and dissemination of information, research and development, local empowerment, legitimacy and trustworthiness, monitoring and feedback, adaptive leadership and affective co-management, a participatory approach to decision-making, cooperation and conflict resolution [12]. These principles enhance the effectiveness and efficiency in natural resource management, while supporting communities socially, economically and educationally. CBNRM struggles when it is imposed by external institutions, such as donors and governments. CBNRM, forest certification, market access for Non-Timber Forest Products (NTFP) and ICDP, which were once hailed in tropical forest conservation, did not meet-up to expectations due to the application of impracticable assumptions by external actors, and there is fear that REDD+ might be next on the list [13]. Therefore, there is a need to analyse the progress of REDD+ from an early stage and to adapt strategies that are geared toward appropriate satisfactory outcomes, especially for local communities, to prevent the early failure of initiative. This study seeks to examine "what has been done" by local communities in providing practitioners with useful information (state-of-the-art) that needs to be considered in enhancing effectiveness, efficiency and equity in the Mount Cameroon 
National Park (MCNP) REDD+ projects. This study focuses on practical local community engagement within the co-management approach of MCNP.

\section{Background of MCNP Conservation Projects}

MCNP was created in December 2009 and launched in February 2010, to support the conservation of biodiversity, reduce deforestation and land degradation and improve the livelihoods of forest dwellers [14]. The implementation partners include the German International Cooperation Deutsche Gesellschaft für Internationale Zusammenarbeit (GIZ), the World Wide Fund for nature (WWF), the Wildlife Conservation Society (WCS), the Ministry of Forestry and Fauna (MINFOF), the Ministry of Environment, Nature Protection and Sustainable Development (MINEPDED) and local communities. Frank Stenmanns, leader of the Programme Consulting Group (GFA Envest), disclosed a programme to help divert villagers from encroaching into the park through the provision of small income-generating projects, such as improved cocoa and oil palm, domestication of Non-Timber Forest Products (NTFP), improved palm oil and cassava processing and establishment of a community forest. Projects designed for village development plans included pipe-borne water, farm-to-market roads and crop preservation facilities. A financial agreement was signed between Cameroon (Ministry of Finance and MINFOF) and Germany (GIZ) as a development aid for sustainable management of natural resources within the South West Region (SWR), and $€ 7,000,000$ was disbursed [15]. The aim was to sustainably manage forest, promote community participation and alleviate poverty, but this has also increased the grip of MINFOF over local communities. MINFOF depends on GIZ and other Western donors for financing the programme, and this has strengthened their influence in national forest policy and implementation strategies.

The MCNP management involves 41 peripheral villages, which are divided into four geographical clusters (Buea, Bomboko, Muyuka and West-Cost) based on natural boundaries, culture and livelihood differences to facilitate collaborative management activities (Figure 1). A cluster platform is then established to coordinate all activities and entails a constant flow of information between the park managers and park villages. The MCNP REDD+ project is a humid forest zone, which registered the highest deforestation rate (46.2\%) between 1987 and 2010 in Cameroon and has clear site boundaries of project intervention [16].

The Mount Cameroon Prunus (MOCAP) common initiative group is a local CBNRM initiative responsible for the organisation and monitoring of sustainable exploitation and management of Prunus since its establishment in 2005 [17]. Prunus africana is an Afro-montane light-demanding hardwood tree attaining more than $30 \mathrm{~m}$ in height with a rough and dark bark whose thickness varies with age, ecology and size. It is commonly known as Pygeum, a medicinal plant used as a health supplement and for the treatment of prostate cancer, and is a major source of income for forest dwellers and enterprises. It provides about 1320 million FCFA $(\$ 2,686,000)$ export revenue to Cameroon with an annual 2000 tonnes exportation permit [18]. Together with the MCNP management unit, they train villagers on sustainable harvesting techniques; establish inventories of Prunus together with local communities and the National Forest Development Agency (ANAFOR); distribute Prunus seedlings to farmers to be planted into the agro-forestry systems; establish a village development fund in park villages; and reduce illegal exploitation of Prunus [17]. The Ministry of Forestry and Fauna (MINFOF), through the MCNP management unit, is responsible for the sustainable management of Prunus africana. In 2011, the government reviewed its methods of attributing special permits, took an inventory of existing stock, prescribed new sustainable exploitation methods satisfactory to the Convention on International Trade in Endangered Species of Fauna and Flora (CITES) [19] and established the Prunus Allocation Units (PAU). The PAU grants exploitation rights within a specified unit or territory based on the inventory and management plan for that unit. 


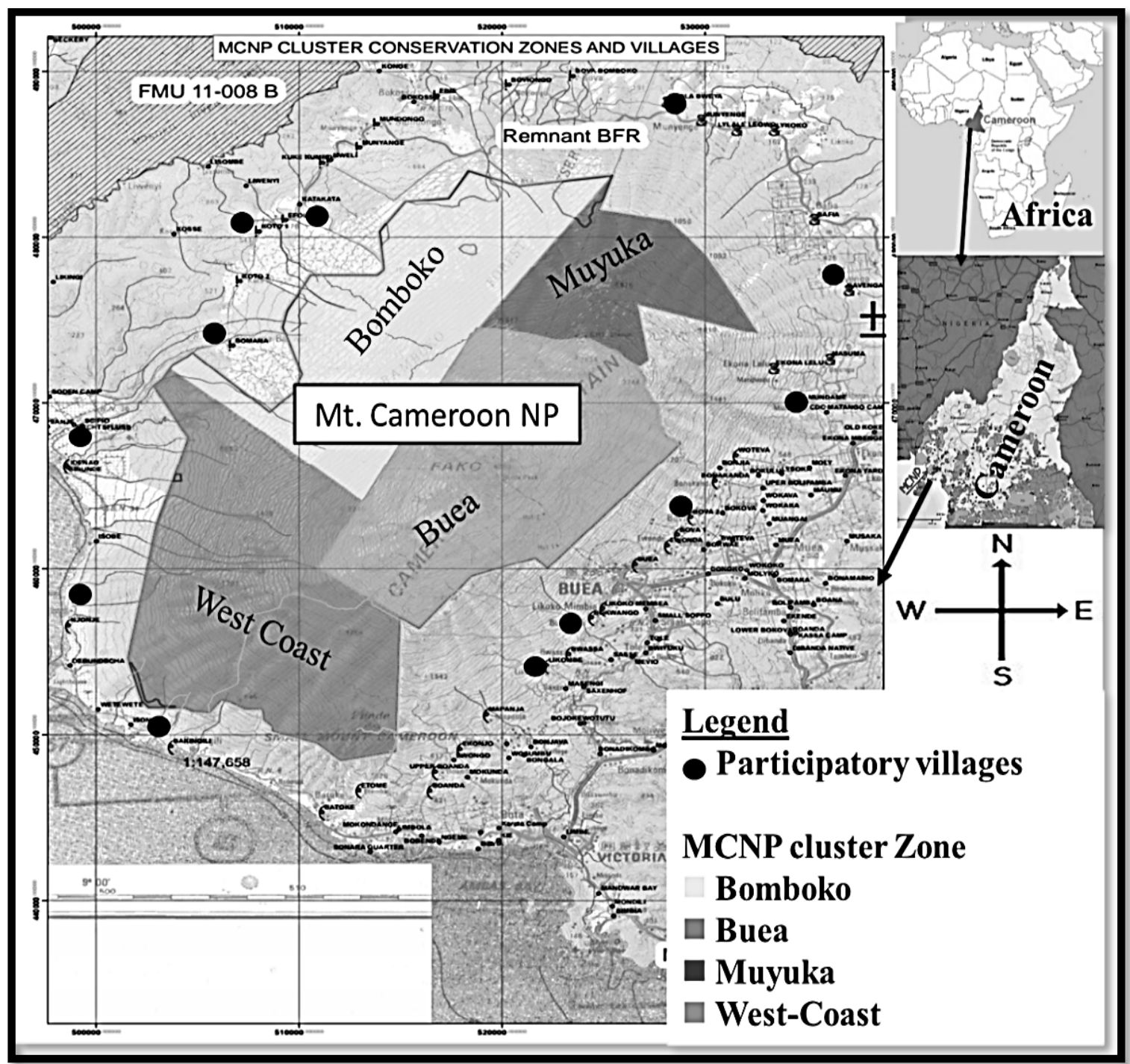

Figure 1. Map of Mount Cameroon National Park (MCNP) showing the cluster conservation zone and participatory villages involved in MCNP REDD+ project. FMU: Forest Management Unit; BFR: Bomboko Forest Reserve.

The PAU is made up of the MCNP and its support zone. MCNP contains about $90 \%$ of exploitable Prunus africana within the PAU, which is divided into five management clusters (3691 ha, 3939 ha, 6291 ha, 12,248 ha and 6699 ha) totalling 32,868 ha [17] (Table 1; Figure 2). Only one cluster is harvested each year with a five-year rotation (quota) Prunus harvesting plan. Healthy trees are harvested, while wilted trees are left untouched, and felling of trees is restricted within the national park. The management plan for Prunus is fully integrated into the park management plan, which is co-managed between park managers and local communities, and its exploitation is in conformity with conservation objectives. The park is aimed at linking conservation, community development, poverty alleviation and improving livelihood. Participation of local communities is an integral part of the Prunus management plan, whereby each village signs a Memorandum of Understanding $(\mathrm{MoU})$ with the park management services. The MoU contains stated roles and responsibilities of the villages and benefit sharing, mechanisms for poverty alleviation that are geared toward sustainable development. Harvesting, trade and management are also done following specified Prunus africana norms. Villagers are also encouraged to regenerate Prunus plantation and integrate Prunus into agro-forestry. Only trained and certified harvesters are allowed to harvest under strict supervision. 
It is believed that through this management plan, the resources are able to regenerate and increase both qualitatively and quantitatively.

Table 1. Density and exploitable Prunus on Mount Cameroon [17].

\begin{tabular}{cccccc}
\hline Location & $\begin{array}{c}\text { Density (Number of } \\
\text { Trees) } \mathbf{d b h}<\mathbf{3 0} \mathbf{~ c m}\end{array}$ & $\begin{array}{c}\text { Density (Number of } \\
\text { Trees) } \mathbf{d b h} \mathbf{3 0} \mathbf{~ c m}\end{array}$ & $\begin{array}{c}\text { Total Density } \\
\text { (Number of Trees) }\end{array}$ & $\begin{array}{c}\text { Stock of Fresh } \\
\text { Bark (tons) }\end{array}$ & $\begin{array}{c}\text { Annual Quota } \\
\text { (tons) R: } \mathbf{5} \text { Year }\end{array}$ \\
\hline National Park & $1.92(27,984)$ & $2.01(28,740)$ & $3.93(56,724)$ & $1,580,701$ & 316,140 \\
Support Zone & $1.65(10,635)$ & $0.79(3758)$ & $2.44(14,394)$ & 206,710 & 41,342 \\
$\quad$ Average & 1.79 & 1.40 & 3.19 & & \\
$\quad$ Total & $(38,454)$ & $(32,498)$ & $(71,117)$ & $1,787,411$ & 357,482 \\
Total Dry Bark & & & & 893,705 & 178,741 \\
\hline
\end{tabular}

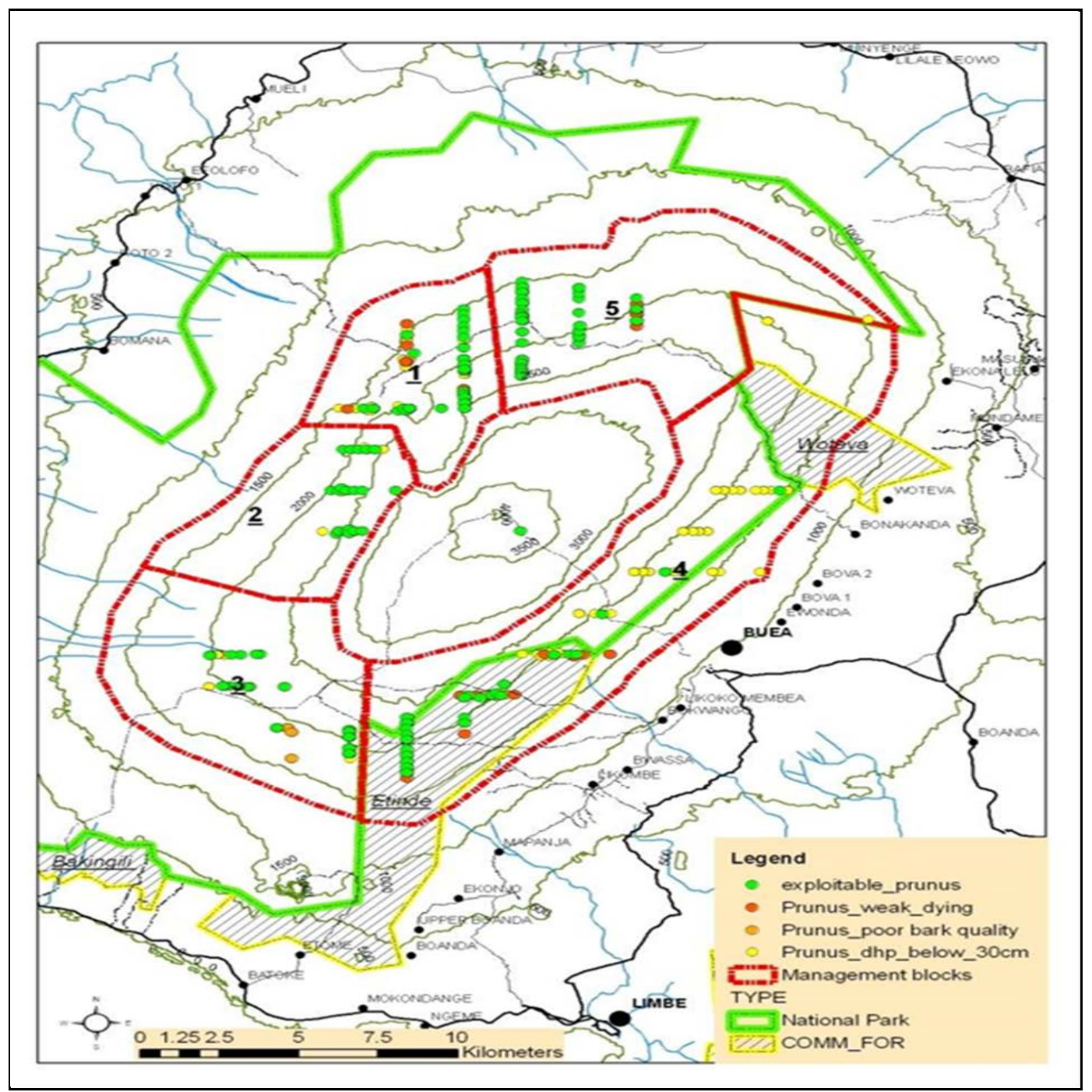

Figure 2. Map of Prunus management clusters as a sub-set of the MCNP management unit showing the distribution of trees [17]. COMM_FOR: Community Forest.

\section{Materials and Methods}

To validate the survey, a pilot study was conducted in one park village in each cluster five months before actual field work (64 respondents). This helps to identify gaps and field challenges, correct inconsistencies and re-structure survey instruments. The result of the pilot study was not included in the final analysis, but falls in line with the final result. Data were collected from October to December 2013. Households formed the basic sampling unit for this study. Only park villages with 
a population between 100 to 1000 inhabitants were included in the survey to improve population representativeness in the survey. A cluster multi-stage random sampling approach was adopted because it captures any random variation in the population. Three villages were randomly chosen within each cluster making sure that they do not share a common boundary (Table 2). From each village, at least $17 \%$ of households, $34 \%$ of each gender and $10 \%$ of each age group at various educational levels participated in this questionnaire survey (259 respondents). Questionnaires were administered face-to-face and had multiple responses, ranking, close-ended and open-ended questions.

Table 2. The four clusters and corresponding villages co-managing MCNP with sampled villages in bold.

\begin{tabular}{ll}
\hline \multicolumn{1}{c}{ Name of Cluster } & \multicolumn{1}{c}{ Park Villages } \\
\hline 1-Buea (Salaried workers) & $\begin{array}{l}\text { Upper Boando, Ekonjo, Mapanja, Likombe, Bwassa, Bokwango, Lykoko } \\
\text { Membia, Buea village, Ewondo, Bova 1, Bova 2, Bonakanda, Woteva }\end{array}$ \\
\hline 2-West-Coast (Fishing) & Sanje, Bibunde, Njonji, Bakingili, Etome, Batoke, Lower Boando \\
\hline 3-Muyuka (Hunting) & $\begin{array}{l}\text { Mundame, Ekona Lelu, Liola-Buea, Masuma, Bavenga, Bafia, Lykoko, Mile 14, } \\
\text { Liliale, Munyenge }\end{array}$ \\
\hline 4-Bomboko (Timber) & $\begin{array}{l}\text { Bova Bomoko, Boviongo, Ebie, Bokoso, Mondongo, Munyange, Mueli, } \\
\text { Kukekumbu, Efolofo, Kotto 1, Kotto 2, Bomana }\end{array}$ \\
\hline
\end{tabular}

A focus-group discussion forum was set-up within each participatory village involving the chief, councillors and five representatives from the local community. The discussions empowered participants to reveal self-directed debates about their views, knowledge, values and practices [20]. These results (focus group) provide a better understanding of communities' perception and help to validate quantitative results. The principal investigator chaired the focus group discussions, while one assistant took down notes and another recorded the discussion on tape to facilitate the analysis of unclear statements. This was carried out before the household survey to enhance acquaintance and acceptance of the research assistants by community members.

Consultations and interviews were conducted with key proponents from the Mount Cameroon Prunus Common Initiative Group (MOCAP-CIG), the German International Cooperation (GIZ), the Ministry of Environment, Nature Protection and Sustainable Development (MINEPDED), the Ministry of Forestry and Fauna (MINFOF) and Planet Survey. Face-to-face interviews were used to collect insight and validate information collected from secondary sources. Field observation and socialization were carried out to attain familiarization with members of communities and the collection of data without affecting their feelings, attitudes and behaviours [20] by participating in local activities, like fishing, farming, story-telling at the village square, singing and dancing to traditional rhythms.

Data were analysed through a mixed-method approach, which integrated both quantitative and qualitative analysis to provide a better understanding of the results [21]. Quantitative results show the results between different clusters, as well as between local participants and non-participants (horizontal analysis), while qualitative results cut through all levels of governance-international, national, sub-national, local groups and local communities (vertical analysis) involved in the MCNP REDD+ project. All validated data from the questionnaire and focus group were coded, entered into Excel and later imported into SPSS for analysis. Descriptive statistics reveal the demographic characteristics of respondents and produce relevant charts. The Mann-Whitney U test, $t$-test and linear regression models were used to understand the contribution of predictors on independent variables. The independent samples Kruskal-Wallis test and Jonckheere-Terpstra trends compare the results between different clusters and established trends, respectively. Interview transcripts were analysed using thematic- and issue-based content analysis (NVivo), and relevant information was incorporated into the quantitative results. Data relationships were examined, information cross-examined, relationships investigated and models established to support the project. 


\section{Results}

Few members of the Bomboko and Buea clusters $(<2 \%)$ have been involved in forest management projects before 2005. With the launch of MCNP in February 2010, all four clusters have become engaged in forest management projects, and in 2012/2013, 17\% of respondents participated in park activities (Figure 3A). Before the creation of the park, communities' common forest practices included protection of specific tree species, education on forest management, mapping/inventory of forest resources, enactment of forest by-laws, cutting down of competing trees and establishment of clear use rights for special products (Figure 3B).

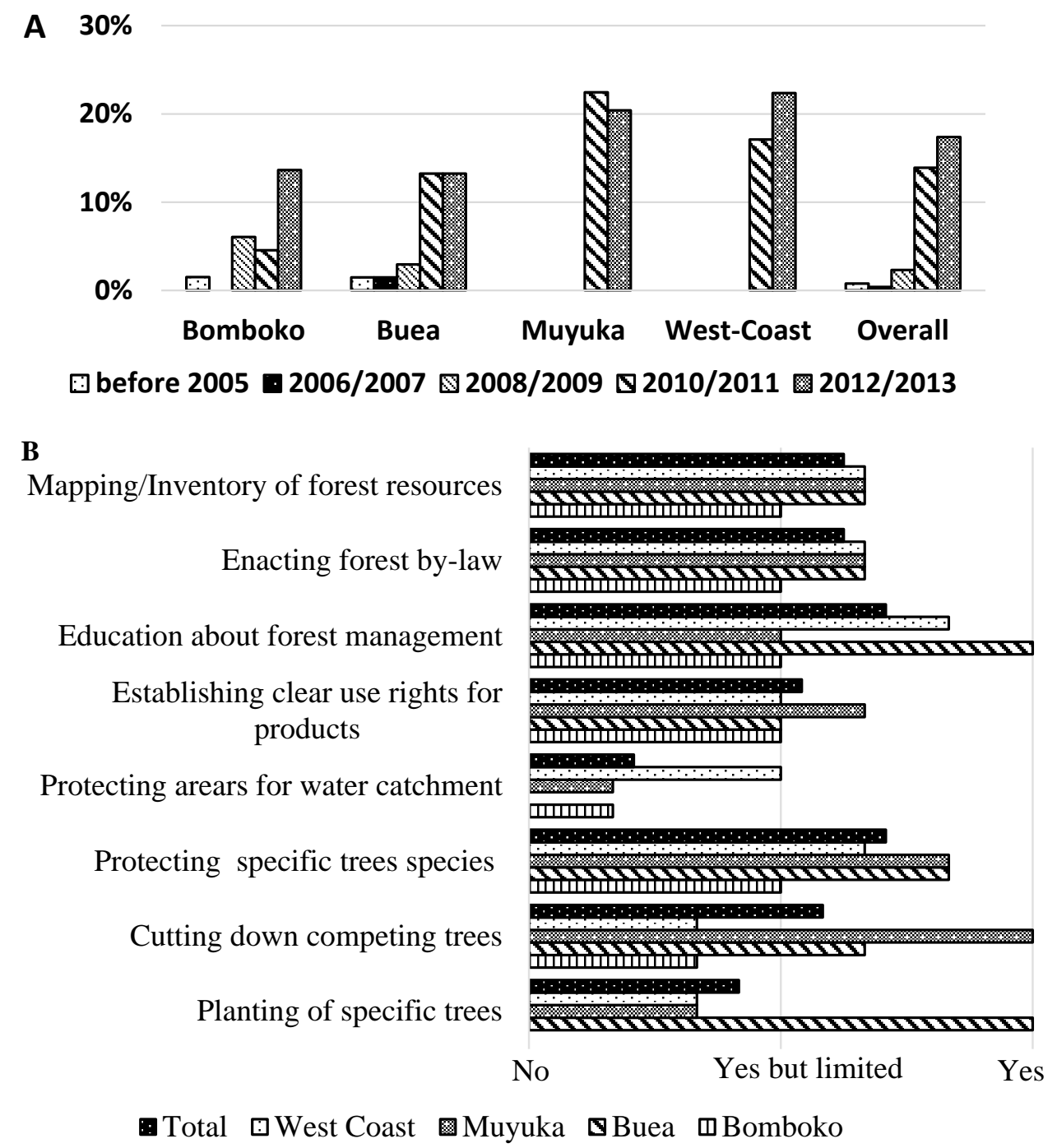

Figure 3. Increased percentage of participants engaged in forest projects with the launch of MCNP (A) and common forest practices before the launching of the park (B).

\subsection{Community Perception towards Establishing a Strict Conservation Zone}

A Kruskal-Wallis test shows a significant difference in perception that a strict conservation zone enhances the efficiency of conservation within different clusters $(\mathrm{H}(3)=12.55, p=0.006$ ) (Figure 4A). Pairwise comparison shows significant differences between Muyuka-Bomboko $(\mathrm{H}(3)=37.876, p=0.032$, $z=2.788, r=26 \%)$ and Muyuka-Buea ( $\mathrm{H}(3)=41.158, p=0.014, z=3.049, r=28 \%)$. The result shows a significant trend between the cluster $(J=10,868.5 ; p=0.013, z=-2.493, r=15.5 \%)$ from Buea, Bomboko, West-Coast and Muyuka in descending order with an effect size of $15.5 \%$. The independent sample $t$-test also shows a significant relationship between participation in MCNP activities and the 
perception that a strict conservation zone enhances the conservation initiative $(t=-3.346, \mathrm{df}=257$, $p=0.001)$ (Figure 4B). Results also show significant relationships in Muyuka $(p=0.008)$ and West-Coast $(p=0.004)$ (Figure 4C).

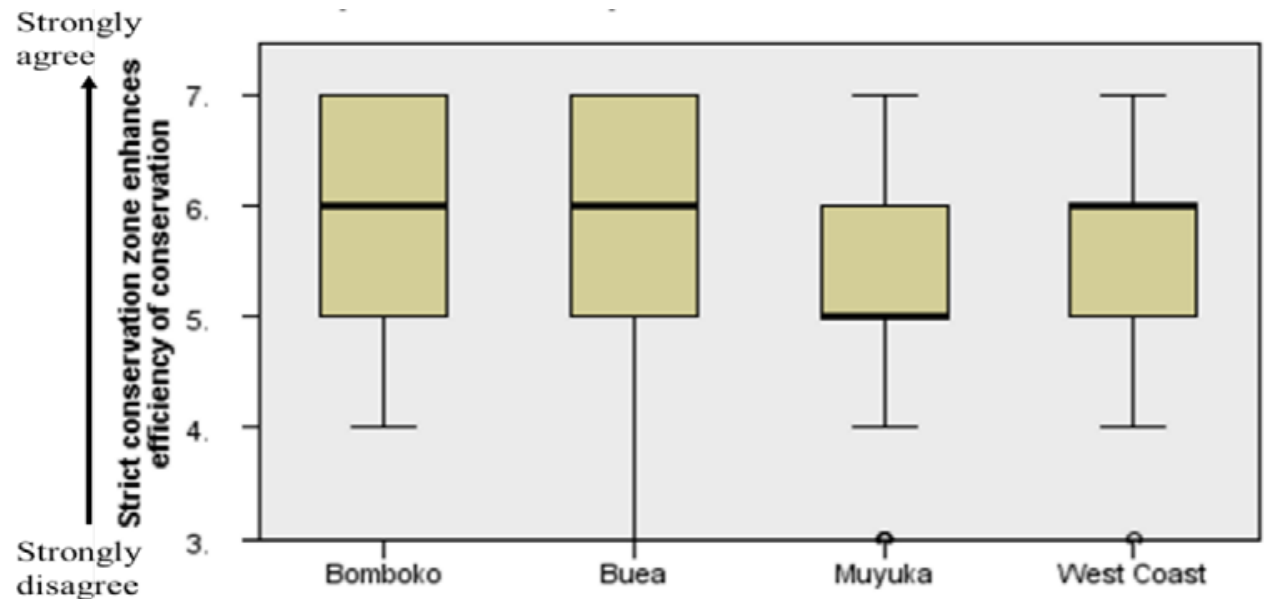

(A)

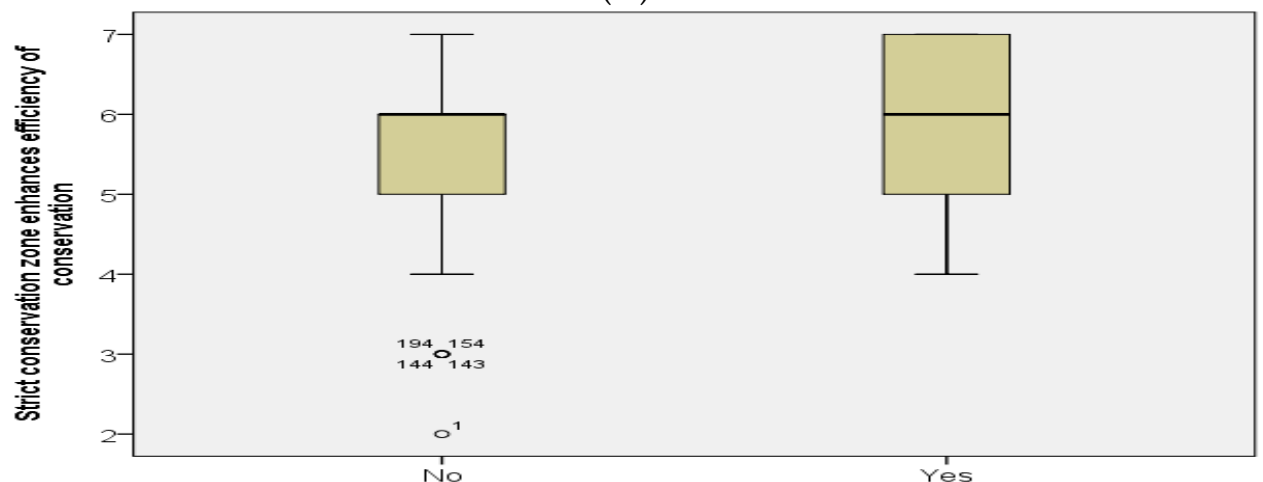

(B)

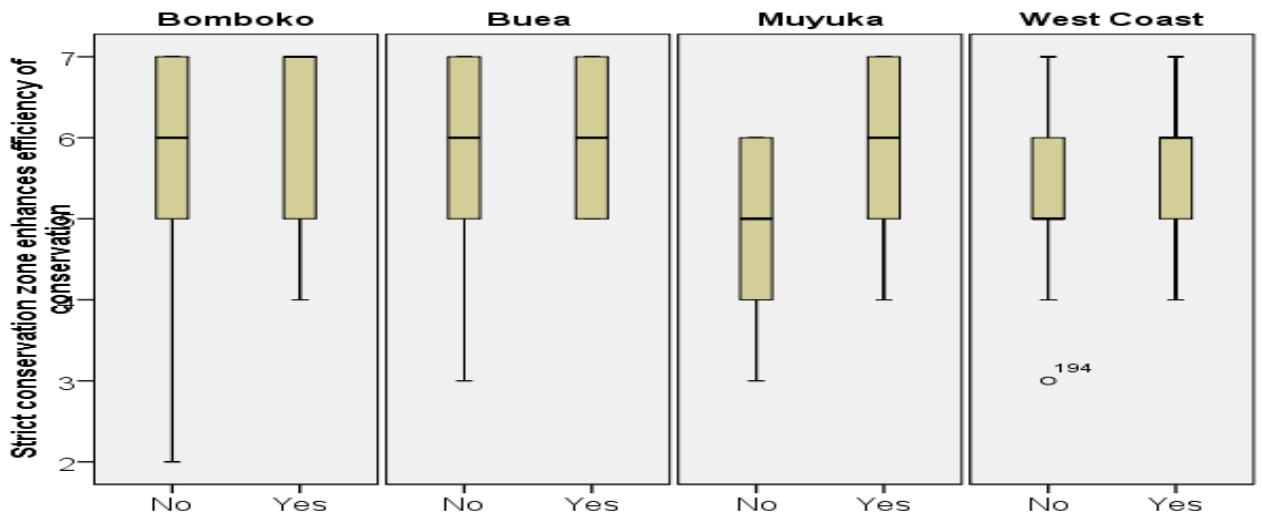

(C)

Figure 4. Kruskal-Wallis plot showing the variance of perception of a strict zone between clusters (A), and $t$-test plots showing how the perception of a strict conservation zone influences participation in MCNP activities in all clusters (B) and within each cluster (C).

The Mann-Whitney $U$ test shows that participation is significantly affected by the perception that a strict conservation zone is necessary to enhance efficiency of conservation $(\mathrm{U}=9332.5 ; p=0.002$; $z=3.129$ ) with an effect-size of $20 \%$ in MCNP clusters. Results reveal significant relationships for Muyuka $(\mathrm{U}=410.5, p=0.015, z=2.436)$ and West-Coast $(\mathrm{U}=922, p=0.009, z=2.614)$ with effect sizes of $35 \%$ and $30 \%$, respectively. Though community perception toward establishing a strict conservation 
zone correlates with engagement, the roles and responsibility of various stakeholders involved in the sustainable management of Prunus (Figure 5) render them less influential stakeholders.

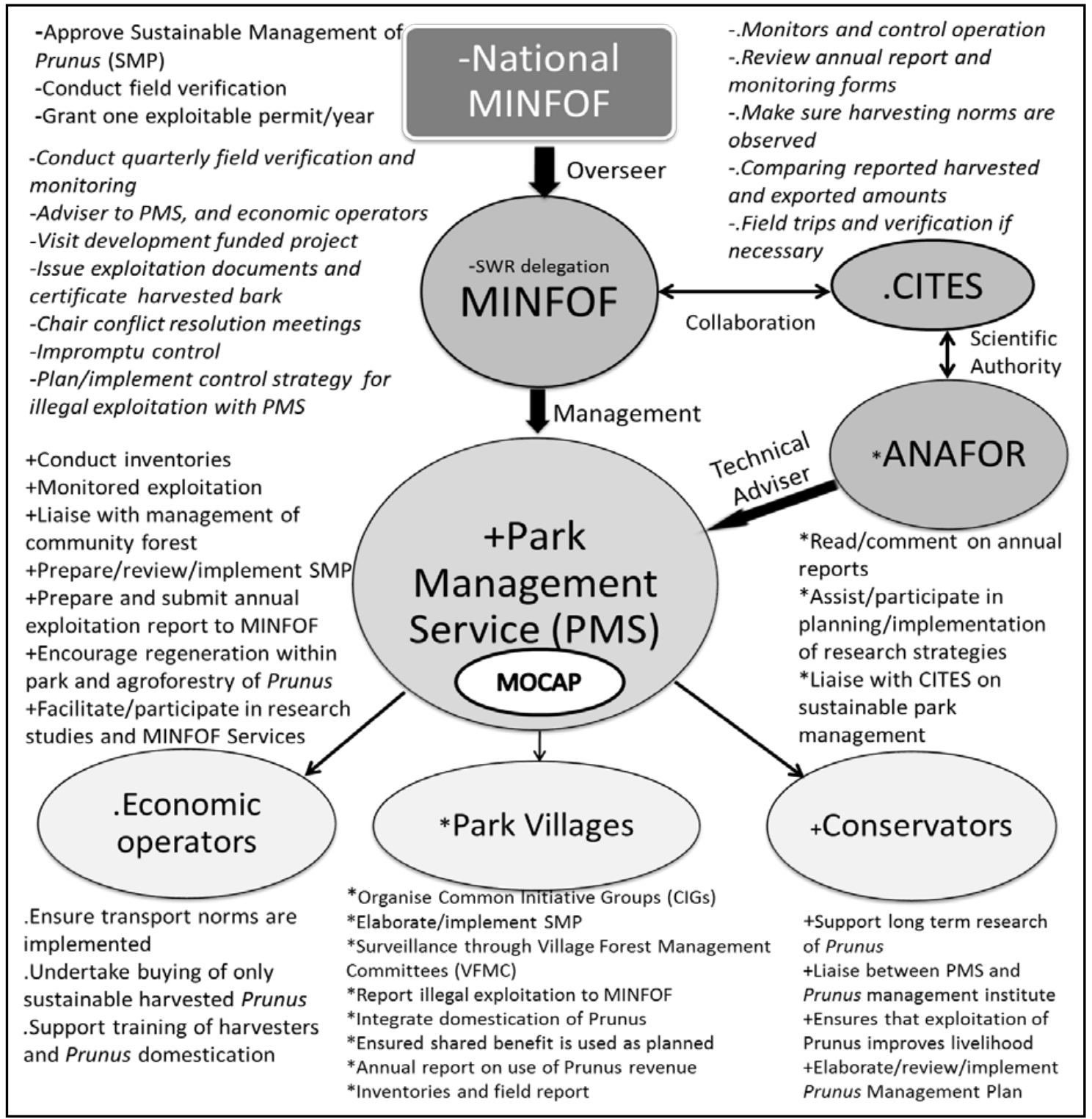

Figure 5. Roles and responsibility of stakeholders in sustainable management of Prunus. MINFOF, Ministry of Forestry and Fauna; MOCAP, Mount Cameroon Prunus; CITES, Convention on International Trade in Endangered Species of Fauna and Flora; ANAFOR: National Forest Development Agency.

The linear regression model presenting how the perception of a strict conservation zone (A) contributes to participation in MCNP activities is significant at $F=11.2, p=0.001$, adjusted $\mathrm{R}=0.038$ and is explained by the following equation:

$$
\text { Participation }=0.827+0.204(\mathrm{~A})
$$

\subsection{Community Support of MCNP Conservation Initiative}

Results show that most members of the community support the MCNP initiative (Figure 6A), because they wish to improve the natural environment, enhance the carbon stock, promote local participation, generate income, promote community development and solve land ownership conflicts (Figure 6B). However, a few members do not support the initiative because of no benefit to them, 
loss of rights over forest, lack of awareness, conflict resulting from spying on each other and exclusion of local people in decision-making (Figure 6C).

A Kruskal-Wallis test shows that the promotion of local participation as one of the reasons for supporting MCNP initiative is significant between clusters $(\mathrm{H}=42.192, p<0.001)$ (Figure 7A). A pairwise comparison shows significant differences between Buea-Bomboko $(\mathrm{H}=58.727, p<0.001$, $z=5.05, r=0.446)$, Buea-West-Coast $(\mathrm{H}=-62.105, p<0.001, z=-5.458, r=0.471)$, Muyuka-Bomboko $(\mathrm{H}=42.368, p=0.004, z=3.393, r=0.391)$ and Muyuka-West-Coast $(\mathrm{H}=-45.747, p<0.001, z=-3.733$, $r=0.342)$.

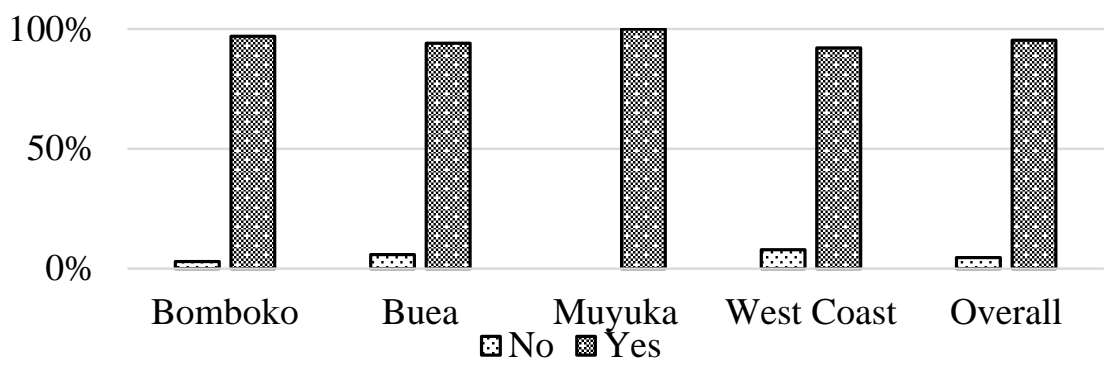

(A)

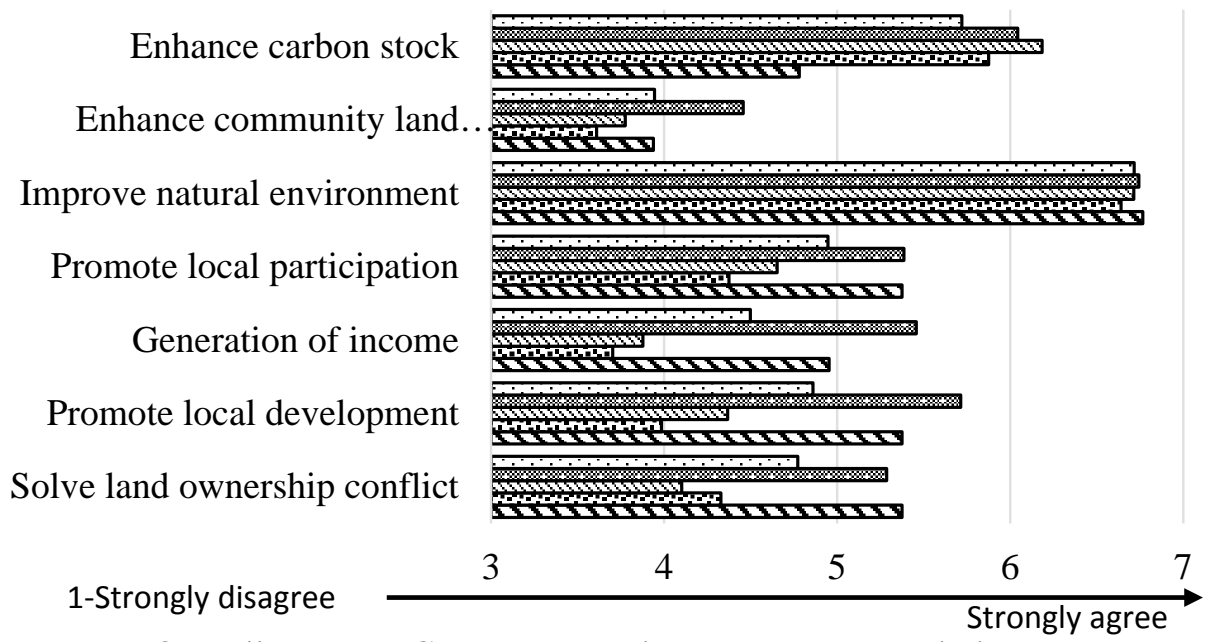

๑Overall 圆West-Coast $₫$ Muyuka \$Buea \$Bomboko

(B)

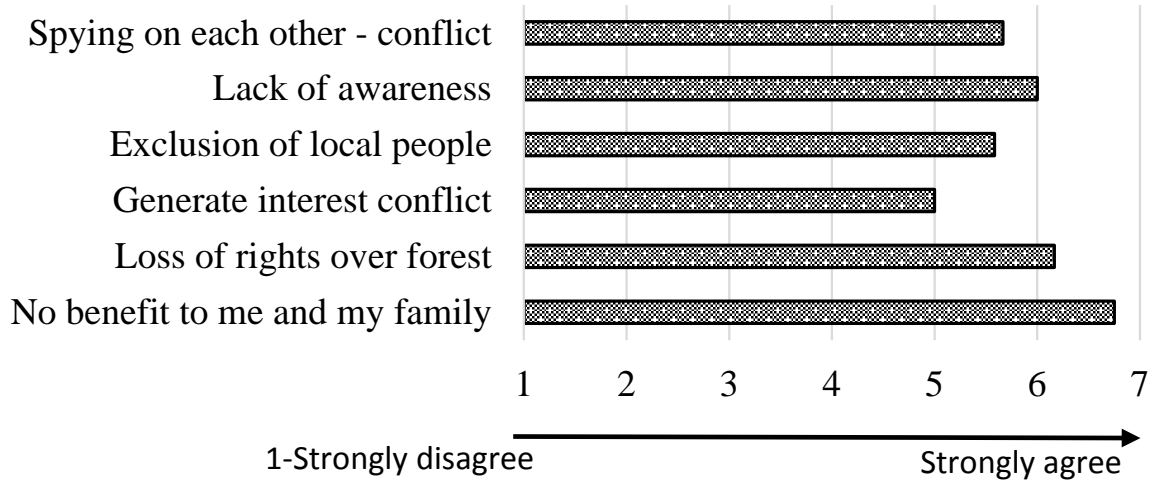

(C)

Figure 6. Percentages of respondents supporting MCNP initiative (A) and reasons for supporting (B) or not supporting (C) MCNP conservation initiative. 
The Kruskal-Wallis test shows that the perception that MCNP will promote local participation is different within clusters (Figure 7A). The independent sample $t$-test shows that participation significantly relates to the perception of promoting local engagement $(t=-6.561, p<0.001)$ (Figure 7B), as well as in each of the clusters $(p<0.05)$ (Figure 7C). A Mann-Whitney test also shows that participation is significantly influenced by the perception of promoting local engagement $(U=9778$, $z=5.452, p<0.001, r=34 \%$ ), as well as in each of the clusters with Bomboko, Buea, Muyuka and West-Coast registering effect sizes of $39 \%, 35 \%, 52 \%$ and $33 \%$, respectively.

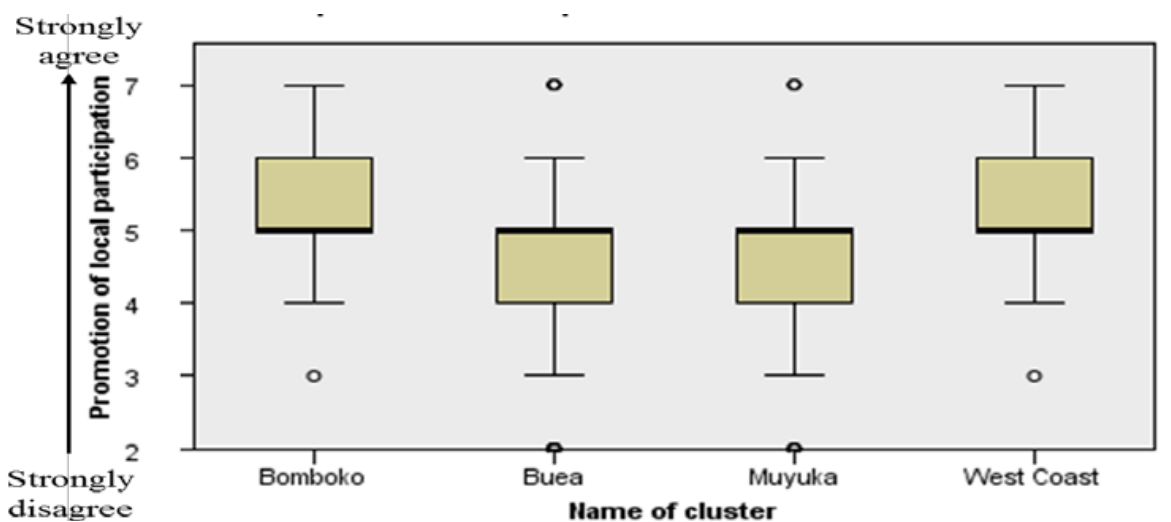

(A)

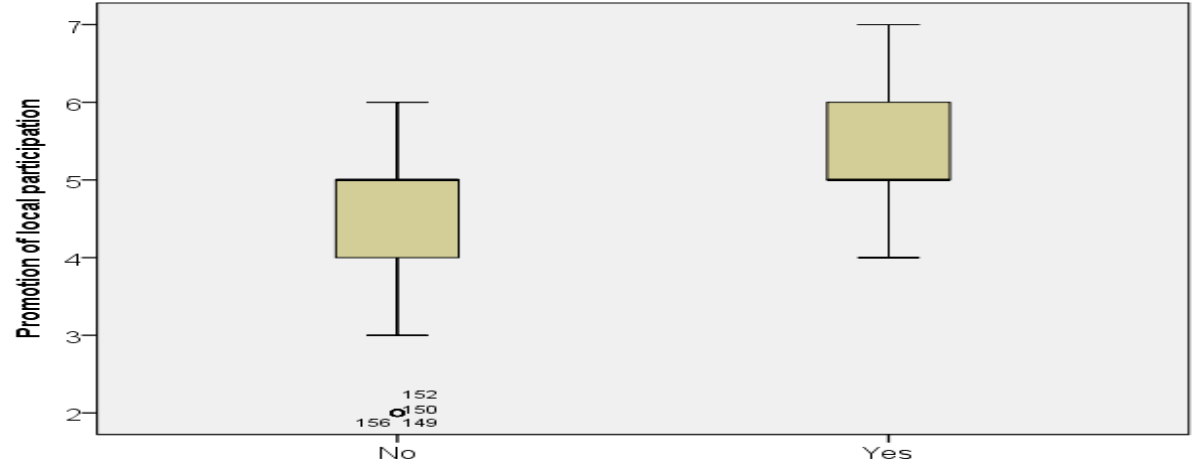

(B)
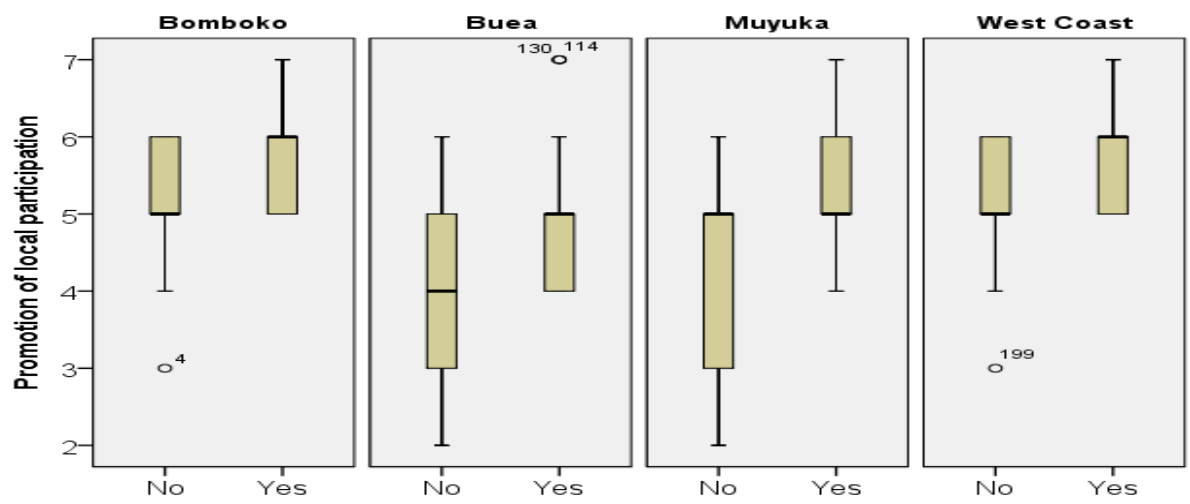

(C)

Figure 7. A Kruskal-Wallis plot showing variance in promoting local participation within clusters (A); and $t$-tests showing how the perception of wanting to promote local participation influences participation in MCNP clusters (B) and within each cluster (C).

The linear regression model, revealing the contribution of the perception of promoting local participation (B) to actual engagement, is significant at $F=36.46, p<0.001$, adjusted $\mathrm{R}=0.126$ and explained in the equation: 


$$
\text { Participation }=0.566+0.360 \mathrm{~B}
$$

\subsection{Influence of Perception of Tenure, Cost-Bearer and Benefactors on Support of MCNP Projects}

Some of the reasons for not supporting the MCNP initiative are because of government ownership (Figure 8A) control (Figure 8B) and decision-making of forest policies (Figure 8C), and these factors also affected participation in MCNP activities even within supporters who decline to participate. Non-supporters perceive that the local communities are bearing the cost of the projects while the government remains as the main benefactor, but the reverse is true for supporters (Figure 8D,E).

A

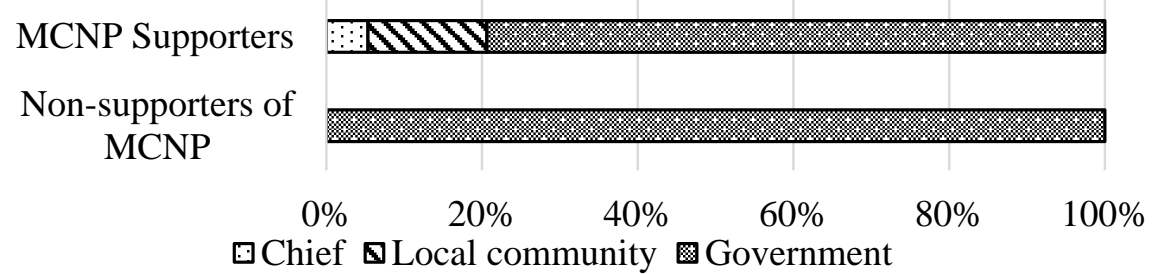

B MCNP Supporters

Non-supporters of

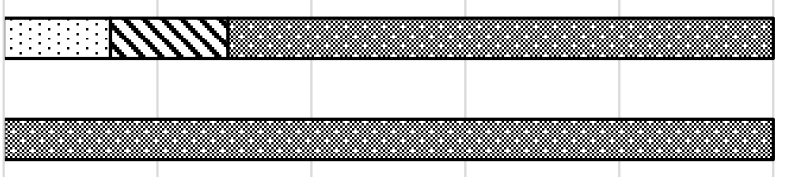

MCNP

$0 \% \quad 20 \% \quad 40 \% \quad 60 \% \quad 80 \% \quad 100 \%$

$\square$ Chief $\mathbf{\Delta}$ Local community $⿴ 囗 十$ Government

C MCNP Supporters

Non-supporters of MCNP

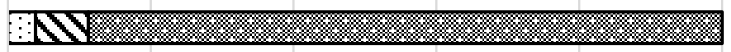

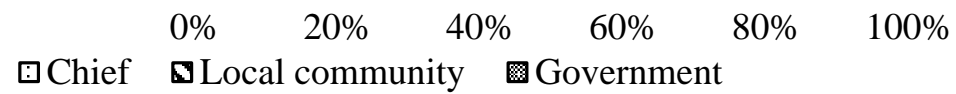

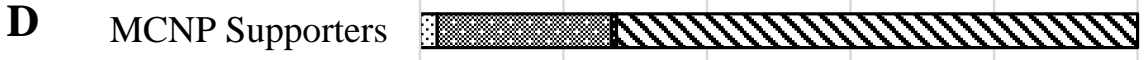

Non-supporters of MCNP

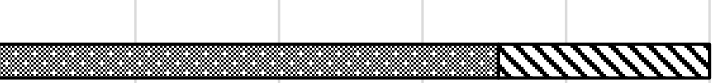

$0 \% \quad 20 \% \quad 40 \% \quad 60 \% \quad 80 \% \quad 100 \%$

๑Chief $\square$ Local community NGO $\mathbf{\Delta G o v e r n m e n t}$

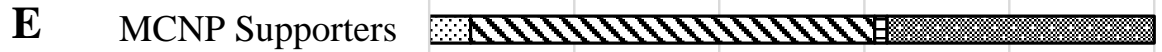

Non-supporters of MCNP S110111

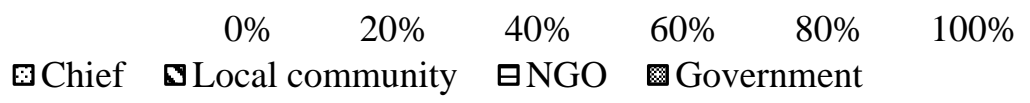

Figure 8. Variance of forest ownership (A), control (B), policy makers (C), cost bearers (D) and benefactors (E) between supporter and non-supporters of MCNP projects.

\subsection{Level of Engagement in MCNP Activities}

Though $95.4 \%$ of respondents supported MCNP, only 34.7\% have ever taken part in forest management projects (Figure 9A), one of the reasons being that most of them have never been invited to participate, especially in Bomboko (Figure 9B), which also shows the lowest percentage in participation. 
Respondents are therefore seeking for more mobilisation and sensitisation, direct employment and incentives to get them on board (Figure 9C).

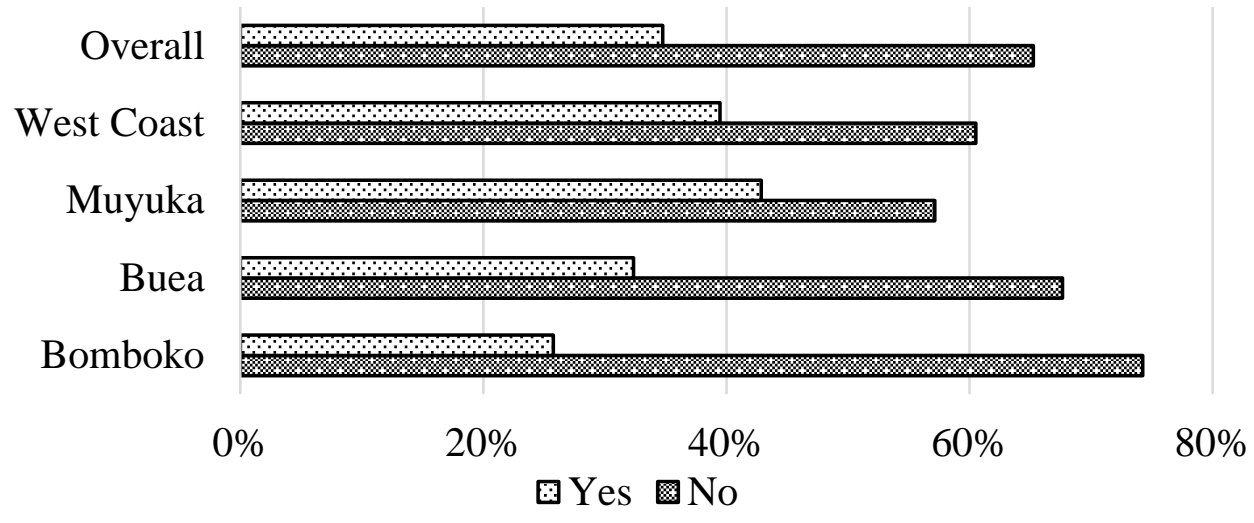

(A)

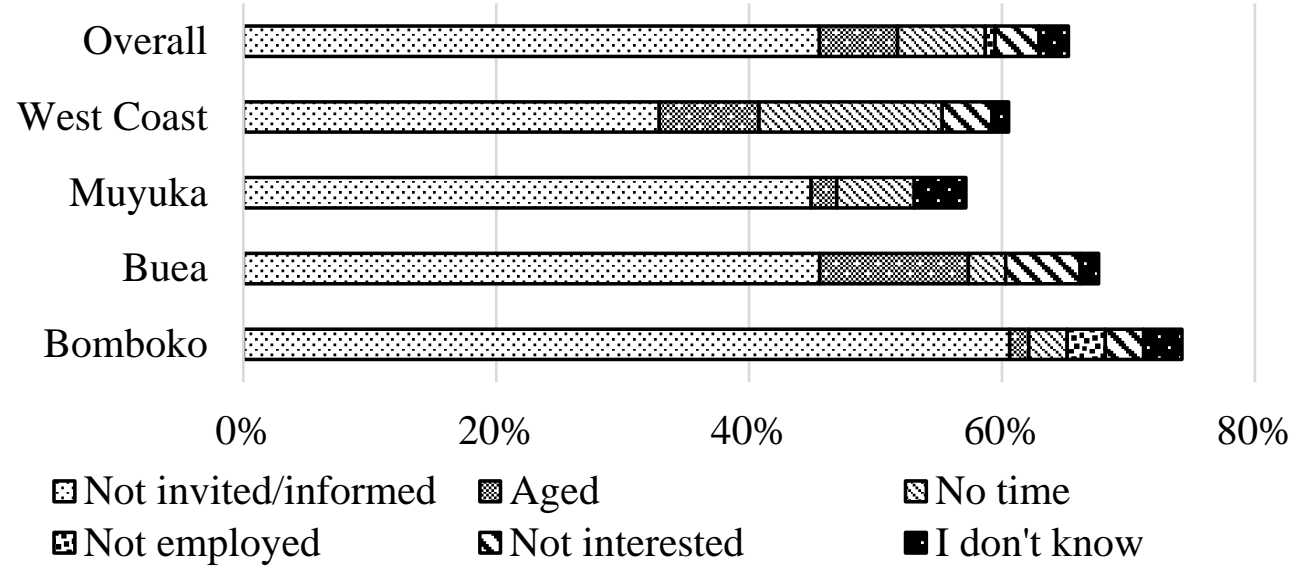

(B)

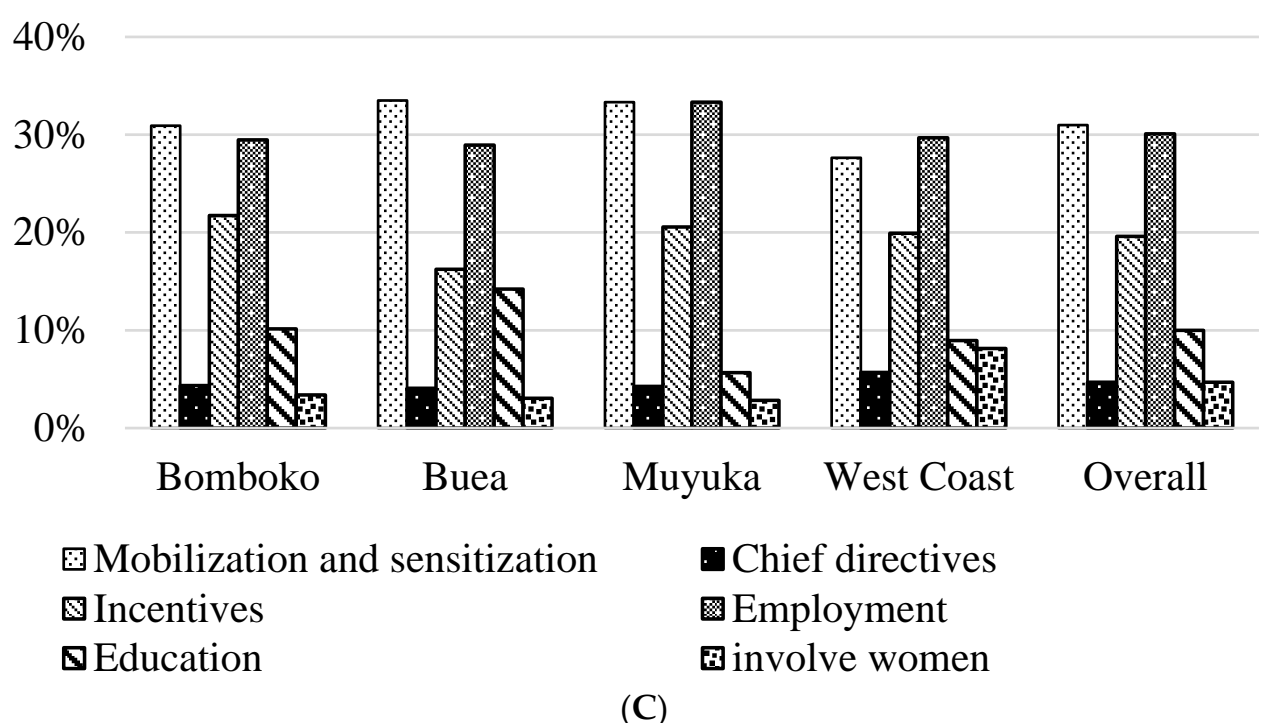

Figure 9. Percentages of local communities' member that have ever participated (A), reasons for not participating (B) and ways to enhance participation (C) in MCNP activities.

Although results show that only $1.9 \%$ of respondents have ever heard of REDD+, they were all aware of projects like the conservation of MCNP, sustainable management of Prunus and/or 
reforestation/tree planting, which are an integral part of MCNP-REDD+ projects (Figure 10A). Though 14 different functions/roles are carried out by local participants, results show that they are mostly involved in manual labour (one-off involvement) or being members of a committee, whose main role is to enforce regulation within their community; therefore, real engagement is negligible (Figure 10B).

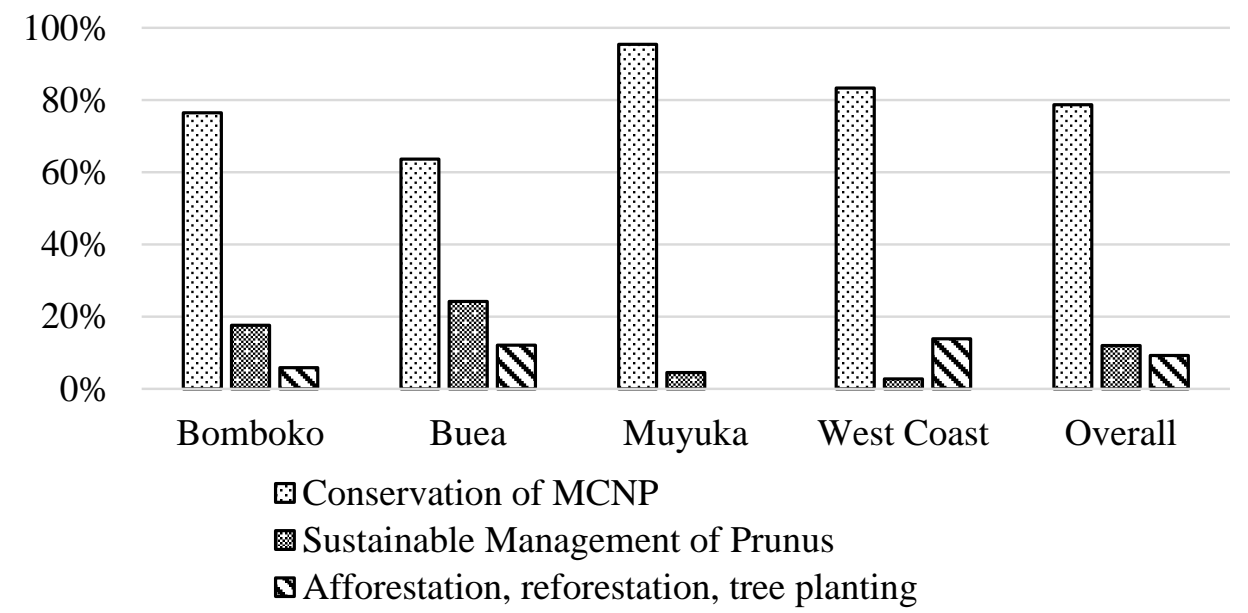

(A)

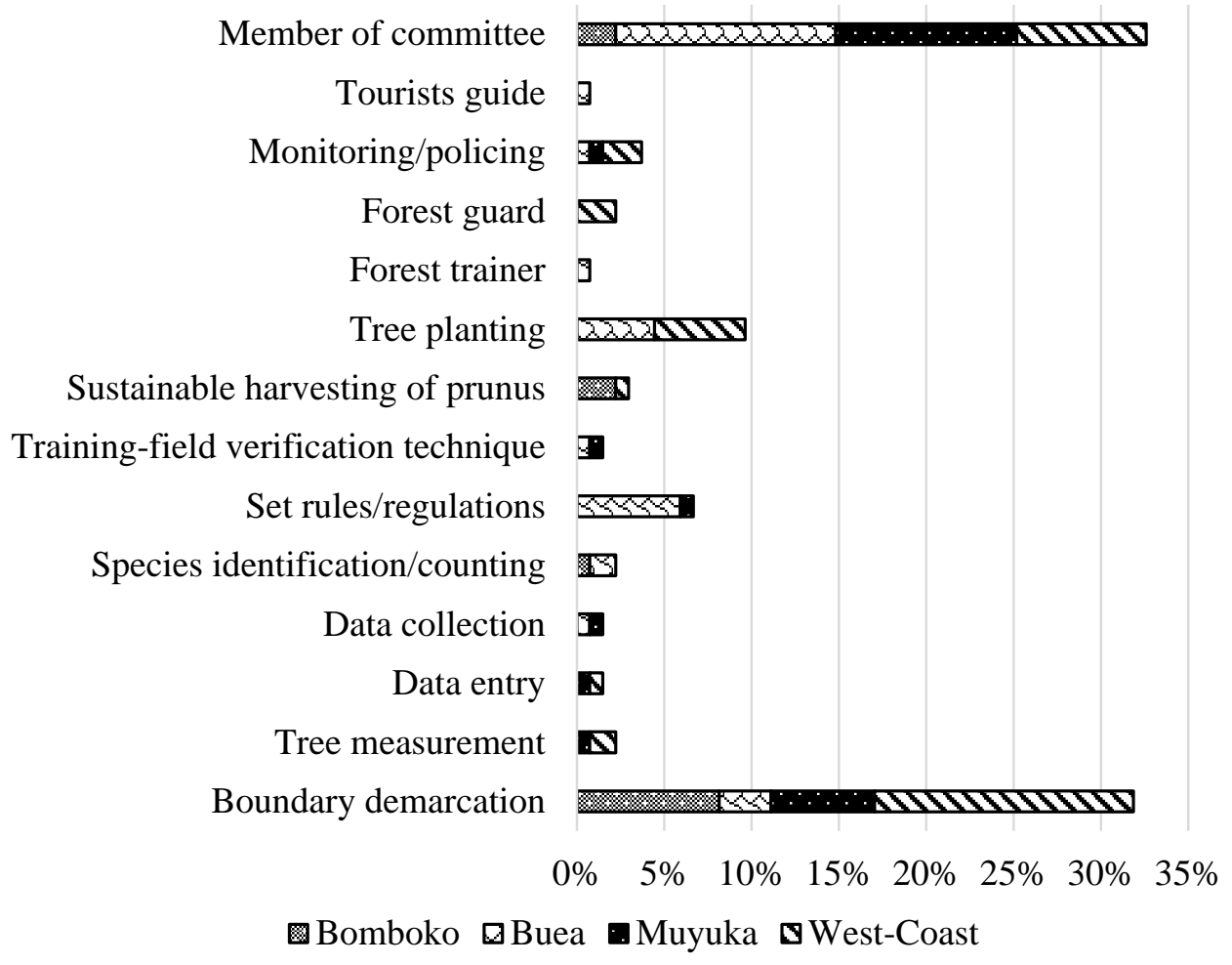

(B)

Figure 10. Percentages of different projects participated in (A) and function/role carried out (B) by participants within all clusters.

An average of six to 10 members have been trained to carry out forest activities (Figure 11A), but most community members do not know how many members have been trained (especially in Bomboko, Buea and West-Coast). Seventeen percent of respondents are not aware of any training opportunity, especially in Muyuka (45\%). Figure 11B further shows that $35 \%$ of information recorded by participants concerns illegal activities, especially in Bomboko (42\%). 


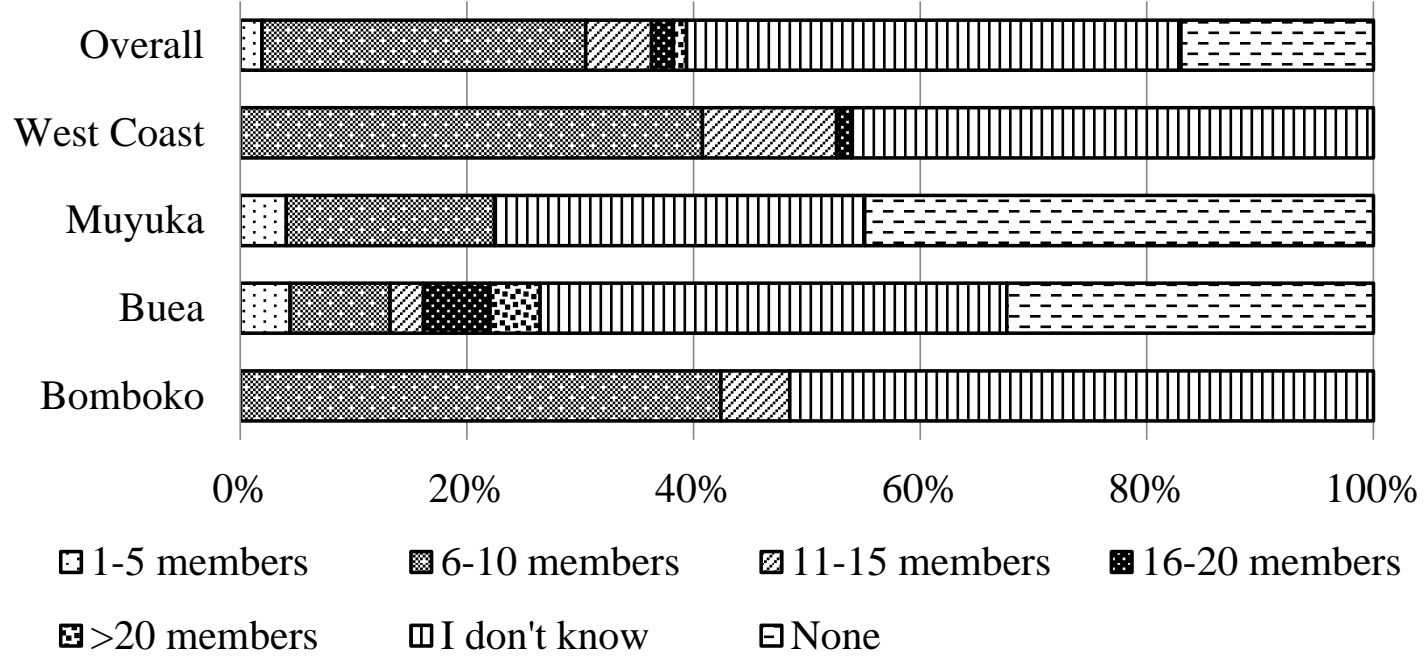

(A)

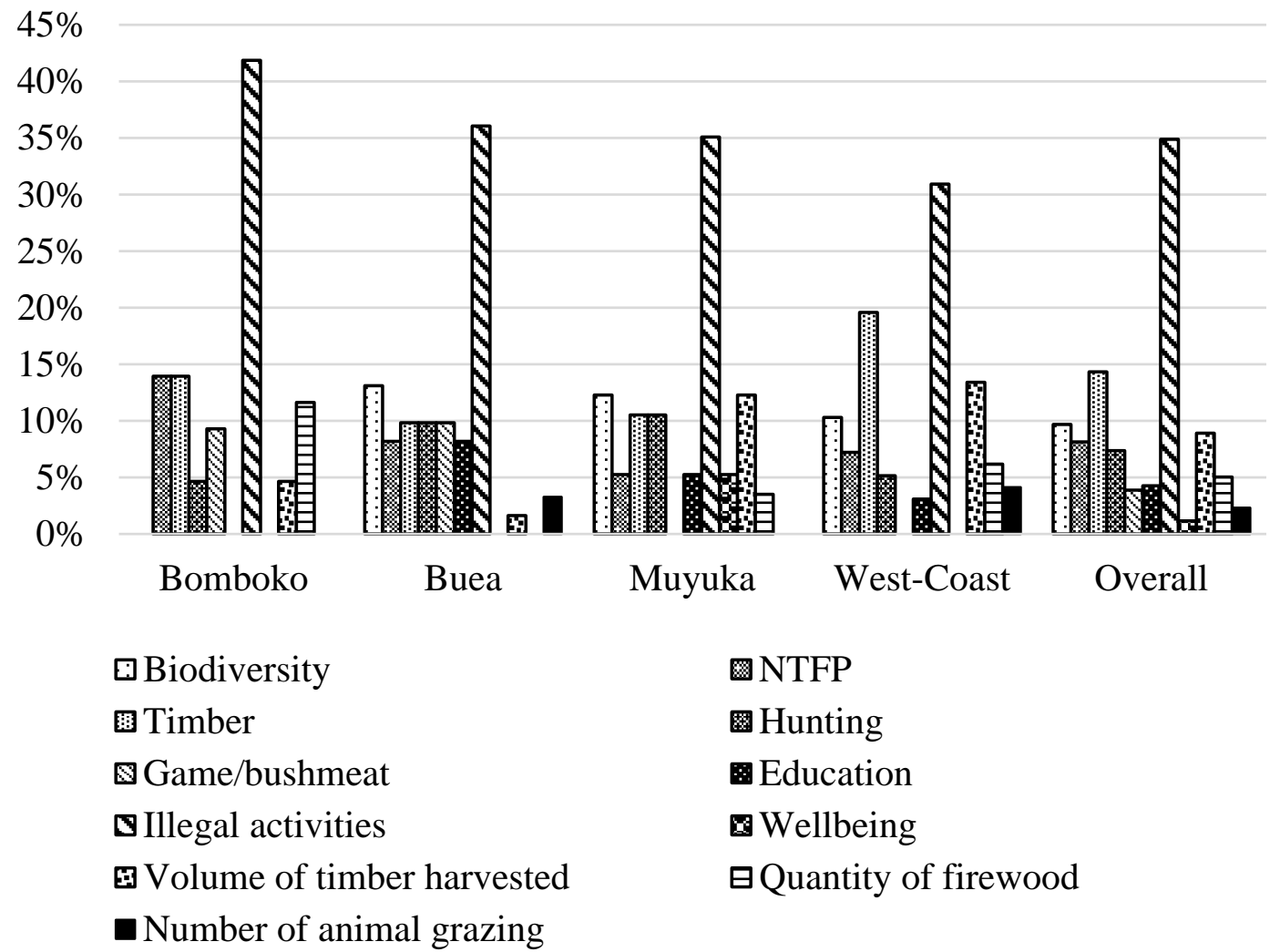

(B)

Figure 11. Percentages of the average number of community members trained for (A) and types of information recorded during (B) MCNP activities.

Only $11.8 \%$ of respondents have used electronic devices in carrying out any MCNP-activities (Figure 12A). These instruments include GPS, camera and phones, which are mostly used in theWest-Coast, followed by Buea, Bomboko and Muyuka (Figure 12B). Other non-electronic devices, like cutlasses, are also being used, though $6 \%$ of participants do not know if there is any use of equipment (Figure 12C). 


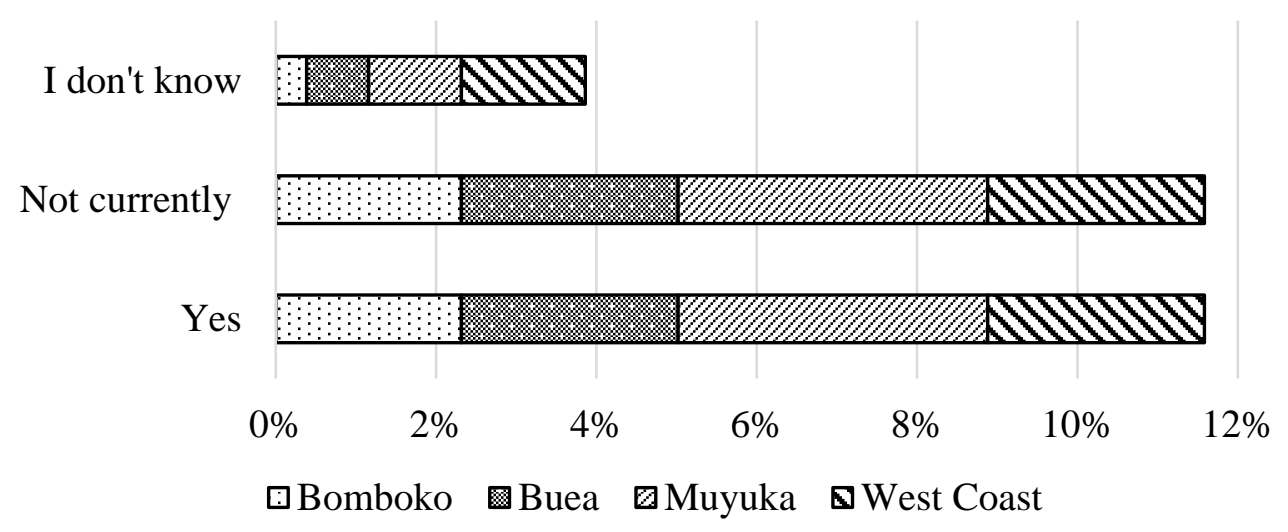

(A)

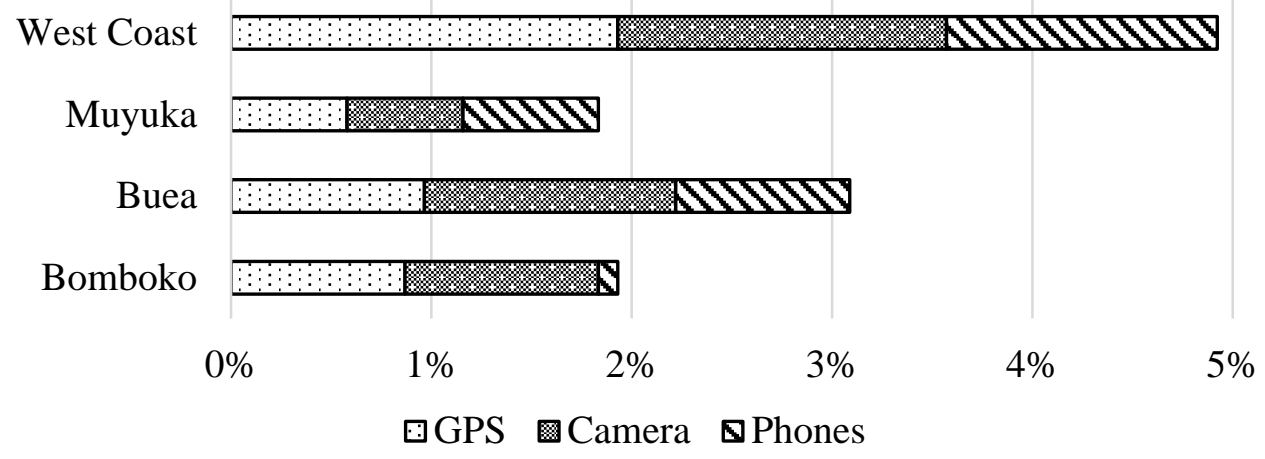

(B)

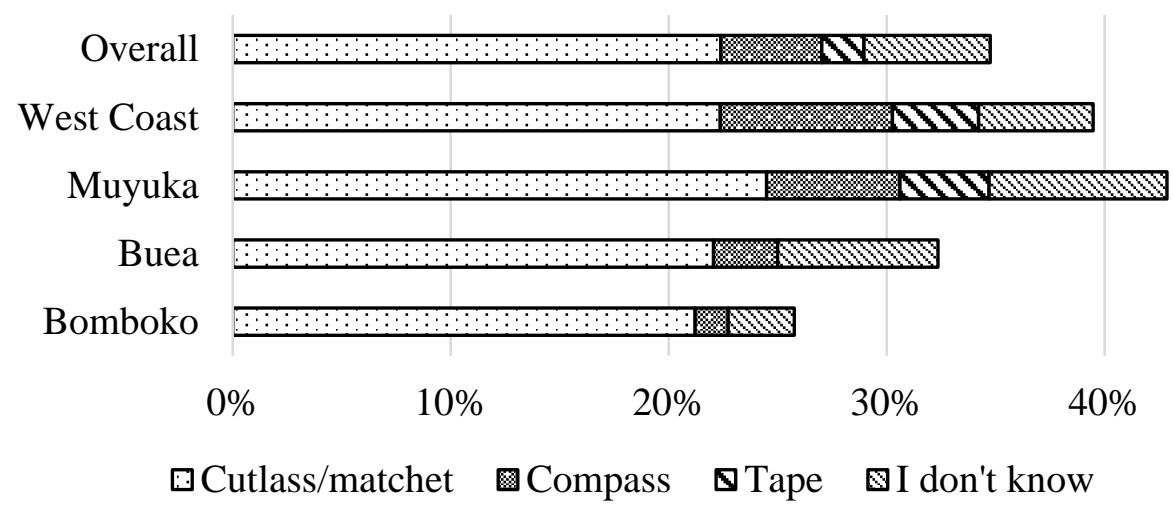

(C)

Figure 12. Percentages of electronic devices used (A), types of electronic devices (B) and non-electronic devices used (C) in carrying out MCNP activities.

\subsection{Qualitative Results}

Respondents talked mostly about two major themes-village community development/benefits and park conservation management activities. The GIZ interviewee perceives the MCNP initiative as having the potential to deliver its sustainable development objective, if and only if the state dominant power structure is diluted to empower local communities' participation, as well as the resolution of other challenges, like migration. Local communities' respondents (LC) are concerned about the lack of employment, financial assistance, agricultural training, as well as other basic necessities. They also show total dissatisfaction in the way communities are treated by park services.

GIZ interviewee reveals a top-down governance approach; whose main reason to include local communities is to amass state benefits; though the national stakeholders assure that they are trying to involve communities. These perceptions contradict the statement by sub-national stakeholders as 
concerns the inclusion of local communities as partners because members of local communities function mostly in cheap labour (demarcating boundaries) and reporting illegal activities, while committee leaders urge their communities' members to implement rules and regulation. The communication approach is more of explanation by park managers and instruction compliance by members of communities, which contradict the co-management approach. Though the sub-national respondent claims that they are not imposing on local communities, the limited function of communities in reporting illegal activities proves that communities are marginalised.

The MOCAP respondent reveals the fact that more communities have engaged in forest projects since the creation of MCNP, and Prunus harvesting, though strenuous, is now done in a sustainable way. Though communities are preserving plant species and felling some, they pride themselves as forest custodians and score their conservation effort at $80 \%$.

\section{Discussion}

Before December 2009, there were few forest projects operational within MCNP clusters, but communities had already been practicing forest management, such as protection of specific plant species, extension of forest management, inventory of special forest products, enactment of forest by-laws and establishment of clear use rights for specific products, among others. The establishment of MCNP in December 2009 registered an increase in forest project participants. With knowledge of these prior forest practices, it is expected that members of the local community would play a major role in MCNP, but the results fall short of this expectation. Though community perception toward establishing a strict conservation zone correlates with engagement, the roles and responsibility of various stakeholders involved in sustainable management of Prunus renders them less influential stakeholders.

The success of co-management depends on the motivation and active participation of community members [22]. Park managers have used incentives to motivate and influence communities to support MCNP REDD+ projects that have been bestowed on them. Communities are also reluctantly losing their land rights and access rights to forest and forest resources; with the expectation of financial benefits and community development projects. Few community projects have also induced behavioural change within members of local communities who stand to lose expected benefits, in case they resist, and their chance of positive outcomes from the battle is negligible.

\subsection{Community Support for the MCNP Initiative}

REDD+ is now seen as a tool to mitigate deforestation that is fast spreading across tropical forest countries because of the potential to store about $50 \%$ more carbon per unit area than forest outside the tropics. At the sixteenth Conference of Parties (COP-16), a consensus was reached that REDD+ should be carried out in three different phases; developing an action plan, implementation of REDD+ policies and performance-based payment. REDD+ must be implemented in a manner that respects the rights and livelihoods of local communities [23]. How much information do these people have on REDD+? Is it what they want or is it imposed on them? Only $1.5 \%$ of respondents in MCNP communities know the reality of REDD+, though most respondents are aware of the need to reduce climate change, deforestation, tree planting, conservation of forest and biodiversity. REDD+ promoters also promise alternative livelihoods, employment and finance of local projects through a participatory-based approach. With this promise of a better life, these vulnerable communities with limited financial resources have no other choice but to follow reluctantly. We join Fox et al. [24] in showing that communities support conservation and are interested in engaging in alternative income-generating activities. Chowdhury et al. [25] further show that training incentives on alternative income-generation activities and the allocation of agricultural land to forest users (such as community forest) enhance engagement in conservation efforts in natural resource management. We also add that communities perceive the establishment of a strict conservation zone as absolutely necessary in enhancing the conservation effort, and this perception significantly influences participation in MCNP activities. The major reasons why local communities support the conservation initiative 
are to promote local communities' participation, enhance the natural environment, generate income and improve community development. The incentives and information they received motivated communities into supporting the projects, but this may be disastrous if their expectations are not met.

\subsection{Ownership, Control, Decision-Making and Project Benefactors}

Local forest management and access to forest resources are essential in maintaining the functioning of local communities and culture [26] and are also vital in the implementation of sustainable REDD+ projects [27]. However, the processes of forest governance and the outcomes of MCNP-REDD+ initiatives depend heavily on foreign and national stakeholders who apply elements of 'actor-centred power' (trust, incentives and coercion) to influence forest management. They manipulate and marginalised local stakeholders, who, by virtue of their poor financial background, have no choice than to act accordingly, with the expectation of developmental and/or financial benefits. According to Larson and Ribot [28], forest policies and the manner of implementation exclude local poor communities from forest benefits with international and national stakeholders influencing outcomes, while manipulating and marginalising local stakeholders. Krott [29] goes on to state that "those who utilise or protect forests are forced to subordinate their interests to politically determined programmes in the face of conflict" as a result of "external stakeholders and political players availing themselves of power". These findings alongside that of this paper are critical in questioning the effectiveness of the REDD+ concept in achieving socio-economic outcomes.

The concept of Actor-Centred Power (ACP) is "a social relationship, where actor " $\mathrm{A}$ " alternates the behaviour of actor "B" without recognising B's will, while trust is when actor B, accepts actor A's information without proof/check" [30]. Power, which is considered "a hidden factor in development assistance", is evident in MCNP, where external stakeholders have become more influential, while local stakeholders are powerless with no option, but to follow reluctantly. This paper supports Movuh and Schusser [15], who show that MINFOF and GIZ are powerful influential actors determining the outcomes of natural resource management projects in the South West Region (SWR). While local communities are relying on unchecked information from these influential stakeholders, they still comply without checking alternatives because they trust MINFOF-SWR, who also trusted GIZ and the accepted management conditions laid down by them without checking for alternatives. MINFOF and GIZ have become more influential and powerful, while local communities have reluctantly lost their rights over the same forest that they had control of for decades; thereby, rendering common initiative groups and/or village forest management committees ineffective, powerless and often portrayed as captives to incentives (motivations) rather than community representatives.

State ownership of forest is central in Cameroon, and all land without a registered land title is treated as state land. The registration procedure is also inaccessible making the state be in control of most of the land. Ngendakumana et al. [31] argue that the success of conservation and REDD+ implementation cannot be effective without recognition and enforcement of traditional tenure because the institutional and policy frameworks give exclusive land tenure rights to the states, with local farmers having limited access to forest and its resources, which is their source of livelihoods. The Cameroon 1994 Forest Law allows state ownership of the permanent forest domain, but does establish usufruct rights to local communities. This law also enables GIZ, the German Development Bank Kreditanstalt für Wiederaufbau (KfW) and other international organisations to exert more influence in controlling natural resource management policies in Cameroon, which make them become a sine qua non in formulating and implementing forest projects with Westernised political ideology [32] that does not fit local perspectives. Measham and Lumbasi [33] show that CBNRM that are initiated, owned and managed by communities have survived the negative impact of livelihoods and complex governance strategies that resulted from influential actors' management strategies in state-controlled initiatives. We argue that community forest management would be a better option to enable communities to claim ownership of the project, manage it following local perspectives and enhance community benefits and livelihoods. Before the establishment of MCNP, forest resources 
were managed according to customary laws with chiefs as the main administrators. State ownership, control and decisions over forest policies have induced some community members not to support forest projects, and these have significantly affected participation in MCNP activities. Supporters think that they are the benefactors, while the government bears the cost. However, non-supporters see local communities as cost-bearers and the government as the main benefactor. Who really is the main benefactor? The government, international organisation or local communities? At the moment, the answer is hardly positive for local communities because expectations have not been met, but time will tell about what happens when carbon is sold.

\subsection{Local Engagement and Expectations}

The MCNP-REDD+ initiative is helping to avoid further encroachment and does rehabilitate degraded forest areas, thereby preserving biodiversity and increasing carbon stock. For forest projects to be effective, they need to fit the dynamics of local socio-economic systems, agro-forestry livelihoods and be sensitive to land use constraints to gain local support. Most members of local communities support the conservation initiative, but between 2012 and 2013, only 17\% of respondents took part in MCNP activities because of inadequate information or lack of invitation to participate. Tanvir and Afroze [34] show that proper and adequate sensitization of communities produces valuable impacts on conservation initiatives, the community and the state. We add that planned and continuous sensitization is vital in co-management and should be enhanced within MCNP to enable the sustainability of the conservation initiative and the community. The high level of community support shows that they are eager and willing to engage, but the big question is: "Why are local communities members not given the chance to take up positions and continue with or enhance their common forest practices?" Even those that are opportune to take part are not taking up any tangible positions. Instead, they are used as manual labourers (boundary demarcation, tree planting, reporting illegal activities) or mere committee members whose main role is to enforce rules/regulations within communities. An average of 6 to 10 members has been trained from each cluster, which is relatively low $(2.57 \%)$ to provide the capacity needed to embark on meaningful participation. This also justifies why the three major activities/roles carried out by participants are being members of committee, boundary demarcation and tree planting, which requires just manual labour. Improved training and education on forest/REDD+ issues will enhance local participation.

According to Kremen et al. [35], conservation benefits are global, but cost is mainly incurred by local communities who must forgo exploitation rights and restriction from forest and forest resources for the sake of conservation, despite high cultural and livelihoods implications. Past PES programmes showed mixed results in benefits to local communities [36]. The clean development mechanism did not result in any substantial benefits to the poor and rural farmers, despite its sustainable development objectives, due to a lack of the recognition of customary land claims [37]. In 2000, the Plantecam enterprise sold Pygeum at 2000 FCFA $/ \mathrm{kg}$, and in 2006 the export value was about 2649 million FCFA with a price ranging from 660 to 1000 FCFA/kg [17]. Despite the high price of Prunus, only 150 FCFA is being paid to harvesters because of a lack of market, information dissemination and market monopoly by park managers. Given the availability of capital, more value could be added to Pygeum through production and transformation (drying, chipping and extraction). Adequate incentives, income generation, alternative livelihoods, community forestry and capacity building of local communities may enhance effectiveness in co-managing MCNP conservation projects. The government and international organisation have successfully used the element of trust and incentives to place local communities under their influence. It is now left for them to prove their trustworthiness because there is yet no meaningful community development or income generated through employment to improve livelihoods. 


\section{Conclusions}

Forest policies should be able to support project activities that yield desirable outcomes without marginalising local communities, by clarifying and securing the community rights, recognising and integrating customary practices and values in the REDD+ governance strategies. Despite local communities' support of MCNP-REDD+ projects, forest managers have taken advantage of communities' voluntary/cheap labour, who trust forest managers to compensate them, by providing socio-economic benefits and improving livelihood. While MINFOF and GIZ are becoming more influential, communities are losing their rights over decades of standing control of forest, thereby rendering members of committees powerless and making them captives to motivations rather than community representatives. Some members of local communities do not support the conservation project because of the perception that their land rights had been seized, and this has also affected engagement. Members of MCNP clusters have for decades lived and derived their livelihood from the forest, and it would sound unbelievable if they cannot enhance their livelihood, alleviating poverty and community development with such a bio-diversifying, rich natural forest as co-managers.

REDD+ programmes should be built on the understanding and scope of forest dependency, and progress and outcome of the programmes should be closely monitored and evaluated, while the use of an adaptive approach to project management should be encouraged. With capacity building among local institutions, REDD+ should be geared towards sustainable development with effective equal local property rights and legal carbon ownership rights while creating a government mechanism that favours co-benefits and the equitable distribution of carbon revenue. The status, context and trend of specific sites need to be known to support the argument and improve capability at negotiation tables accompanied by a solid review of forms of land tenure, available resources and the level of property rights. Members of communities should also be given the opportunity to engage in meaningful positions (like forest guards, species identification and tree measurement), rather than mere labourers. Securing communities' tenure rights and effective engagement in decision-making at cluster platforms is essential in realising MCNP-REDD+ objectives and community adaptive capacity to climate change. Alternative livelihoods, such as animal husbandry, finance for small business and employment (like forest guards and data collectors), should be provided, with schools, hospitals, pipe-borne water, markets established to sell local communities' products and services, as well as the establishment of farm-to-market roads. Above all, good forest projects should be more about recognising the rights of indigenous people, rather than claiming ownership and control of their territory.

As of now, REDD+ is still in the infancy stage and has actually not yielded any substantial income or development for local communities, though expectations remain high. Its threats are evident, but REDD+ has much potential in showcasing the opportunity it holds if carried out through a bottom-top approach where local communities are the main stakeholders and managers of the initiative. Therefore, a trade-off between conservation and development should be acknowledged, negotiated and accepted by both REDD+ promoters and community representatives during project planning to enable realistic appraisal and legitimisation of the conservation initiative. Project design needs to be flexible and based on an adaptive collaborative management approach, which aims at producing appropriate outcomes that render the project more resilient. National-level REDD+ should be subject to adaptation and community development objectives as agreed at COP-18 in Doha.

Supplementary Materials: The interview transcript is available online at www.mdpi.com/2076-3298/3/4/36/s1.

Author Contributions: Nvenakeng Suzanne Awung designed the project, collected the data and analysed the data with guidance from Rob Marchant. The paper was written by Nvenakeng Suzanne Awung and reviewed by Rob Marchant. Rob Marchant supervised the research.

Conflicts of Interest: The authors declare no conflict of interest. No funds have been received for this research. This research has been self-funded by the first author. 


\section{References}

1. Brandon, K.; Wells, M. Lessons for REDD+ from protected areas and integrated conservation and development projects. In Realising REDD+: National Strategy and Policy Options; Center for International Forestry Research (CIFOR): Bogor, Indonesia, 2009; pp. 225-236.

2. Crider, S.T.; Anaya, S.J. Indigenous peoples, the environment, and commercial forestry in developing countries: The case of Awas Tingni, Nicaragua. Hum. Rights Q. 1996, 18, 345-367.

3. Change, I.C. The Physical Science Basis: Working Group I Contribution to the Fifth Assessment Report of the Intergovernmental Panel on Climate Change; Cambridge University Press: New York, NY, USA, 2013; Volume 1, pp. 1-535.

4. Maxime, N.N.L.; Jiwen, G.; Alphonse, N. Assessment of Socioeconomic Factors and Stakeholders Involved in Dzanga Sangha Complex Protected Area, Central African Republic. J. Sustain. Dev. 2010, 3, 273. [CrossRef]

5. Humphrey, D. Logjam: Deforestation and the Crisis of Global Governance; Earthscan: London, UK, 2006.

6. Angelsen, A.; Wertz-Kanounnikoff, S. What Are the Key Design Issues for REDD and the Criteria for Assessing Option; Angelsen, A., Ed.; Center for International Forestry Research: Bogor, Indonesia, 2008; pp. 11-21.

7. Minang, P.A.; van Noordwijk, M. Design challenges for achieving reduced emissions from deforestation and forest degradation through conservation: Leveraging multiple paradigms at the tropical forest margins. Land Use Policy 2013, 31, 61-70.

8. Hughes, R.; Flintan, F. Integrating Conservation and Development Experience; Biodiversity and Livelihoods; IIED: London, UK, 2001.

9. Cerbu, G.; Swallow, B.; Thompson, D. Locating REDD: A global survey and analysis of REDD readiness and demonstration activities. Environ. Sci. Policy 2011, 14, 168-180. [CrossRef]

10. Child, B.; Lyman, M. Natural Resource as Community Asset: Lessons from Two Continents; Sand County Foundation and The Aspen Institute: Madison, WI, USA, 2005.

11. Child, B. Lessons, Experiences, and Critical Conditions for CBNRM. Can Communities Conservation Bring International Goals Down To Earth; Nordic Council of Ministers: Copenhagen, Denmark, 2007; pp. $36-37$.

12. Gruber, J. Key principles of Community-Based natural resource management: A synthesis and interpretation of identified effective approaches for managing the commons. Environ. Manag. 2010, 45, 52-66. [CrossRef] [PubMed]

13. Blom, B.; Sunderland, T.; Murdiyarso, D. Getting REDD to work locally: Lessons learned from integrated conservation and development projects. Environ. Sci. Policy 2010, 13, 164-172. [CrossRef]

14. Moki, S.M. Mount Cameroon Gets a National Park. 2010. Available online: http://www.fakonewscentre.com/ mountcameroonpark.htm?andsession-id=d698178ea9a22b7b6ee0b1c6bff9ec57 (accessed on 14 July 2014).

15. Movuh, M.C.Y.; Schusser, C. Power, the hidden factor in development cooperation. An example of community forestry in Cameroon. Open J. For. 2012, 2, 240-251. [CrossRef]

16. Sunderlin, W.D.; Hatcher, J.; Liddle, M. From Exclusion to Ownership? Challenges and Opportunities in Advancing Forest Tenure Reform; Rights and Resources Initiative: Washington, DC, USA, 2008.

17. Eben, E.S. Prunus Africana Management Plan for the Mount Cameroon National Park and its Support Zone; Regional Delegation of Forestry and Wildlife in Collaboration with the Programme for the Sustainable Management of Natural Resources for the South West (PSMNR-SW) and Local Stakeholders: Buea, Cameroon, 2011; p. 36.

18. Ingram, V.; Nsawir, A.T. Pygeum: Money growing on trees in the Cameroon Highlands? Nat. Faune 2007, 22, $29-36$.

19. Akoa, A.; Betti, J.L.; Ewusi, N.B.; Mbarga, N.; Akagou, Z.H.C.; Fonkoua, C.; Essomba, E.R.; Abia, N.C. Preliminary Report on Sustainable Harvesting of Prunus africana (Rosaceae) in the North West Region of Cameroon. Available online: http://www.itto.int/files/user/cites/cameroon/NDF_Prunus_ANAFOR_ Mount_Cameroon1.pdf (accessed on 17 October 2016).

20. Kvale, S.; Brinkmann, S. Interviews: Learning the Craft of Qualitative Research Interviewing; Sage: London, UK, 2009; p. 233.

21. Bazeley, P. Interpretative analysis strategies for mixed data sources. Am. Behav. Sci. 2012, 56, 814-828. [CrossRef]

22. Thompson, P.; Colavito, L. Economic Value of Bangladesh Wetlands; MACH Technical Paper; The United States Agency for International Development (USAID): Washington, DC, USA, 2007; p. 6. 
23. Sitoe, A.; Salomão, A.; Wertz-Kanounnikoff, S. The Context of REDD+ in Papua New Guinea; CIFOR: Bogor, Indonesia, 2013.

24. Fox, J.; Mustafa, M.G.; Bushley, B.R.; Brennan, S.M.; Durand, L. Connecting Communities and Conservation: Co-Management Initiatives Implemented by IPAC in Wetlands and Forests of Bangladesh; The United States Agency for International Development (USAID): Dhaka, Bangladesh, 2013.

25. Chowdhury, M.S.H.; Gudmundsson, C.; Izumiyama, S.; Koike, M.; Nazia, N.; Rana, M.P.; Mukul, S.A.; Muhammed, N.; Redowan, M. Community attitudes toward forest conservation programs through collaborative protected area management in Bangladesh. Environ. Dev. Sustain. 2014, 16, 1235-1252. [CrossRef]

26. Shepherd, G. Poverty and forests: Sustaining livelihoods in integrated conservation and development. In Getting Biodiversity Projects to Work; McShane, T.O., Wells, M.P., Eds.; Columbia University Press: New York, NY, USA, 2014; pp. 340-371.

27. Peskett, L.; Huberman, D.; Bowen-Jones, E.; Edwards, G.; Brown, J. Making REDD Work for the Poor. Available online: https://www.odi.org/sites/odi.org.uk/files/odi-assets/publications-opinion-files/3451. pdf (accessed on 17 October 2016).

28. Larson, A.M.; Ribot, J.C. The poverty of forestry policy: Double standards on an uneven playing field. Sustain. Sci. J. 2007, 2, 189-204. [CrossRef]

29. Krott, M. Forest Policy Analysis; Springer: Dordrecht, The Netherlands, 2005.

30. Krott, M.; Bader, A.; Schusser, C.; Devkota, R.; Maryudi, A.; Giessen, L.; Aurenhammer, H. Actor-centred power: The driving force in decentralised community based forest governance. For. Policy Econ. 2014, 49, 34-42. [CrossRef]

31. Ngendakumana, S.; Minang, P.A.; Feudjio, M.; Speelman, S.; Van Damme, P.; Tchoundjeu, Z. Institutional dimensions of the developing REDD+ process in Cameroon. Clim. Policy 2014, 14, 769-787. [CrossRef]

32. Movuh, M.C.Y. The Colonial heritage and post-Colonial influence, entanglements and implications of the concept of community forestry by the example of Cameroon. For. Policy Econ. 2012, 15, 70-77. [CrossRef]

33. Measham, T.G.; Lumbasi, J. Success factors for Community Based Natural Resource Management (CBNRM): Lessons from Kenya and Australia. Environ. Manag. 2013, 52, 649-659. [CrossRef] [PubMed]

34. Tanvir, O.F.; Afroze, Z.A. Role of Community Youths in Conservation of Forests and Protected Areas of Bangladesh. World Academy of Science, Engineering and Technology. Int. J. Soc. Behav. Educ. Econ. Bus. Ind. Eng. 2016, 10, 230-233.

35. Kremen, C.; Niles, J.O.; Dalton, M.G.; Daily, G.C.; Ehrlich, P.R.; Fay, J.P.; Grewal, D.; Guillery, R.P. Economic incentives for rain forest conservation across scales. Science 2000, 288, 1828-1832. [CrossRef] [PubMed]

36. Pagiola, S. Payments for environmental services in Costa Rica. Ecol. Econ. 2008, 65, 712-724. [CrossRef]

37. Boyd, E.; Gutierrez, M.; Chang, M. Small-scale forest carbon projects: Adapting CDM to low-income communities. Glob. Environ. Chang. 2007, 17, 250-259. [CrossRef] 